\title{
State of Stress from Focal Mechanisms Before and After the 1992 Landers Earthquake Sequence
}

\author{
by Egill Hauksson
}

\begin{abstract}
The state of stress in the Eastern California Shear Zone (ECSZ) changed significantly because of the occurrence of the $1992 M_{W} 6.1$ Joshua Tree and the $M_{W} 7.3$ Landers earthquakes. To quantify this change, focal mechanisms from the 1975 Galway Lake sequence, the 1979 Homestead Valley sequence, background seismicity from 1981 to 1991 , and the 1992 Landers sequence are inverted for the state of stress. In all cases, the intermediate principal stress axis $\left(S_{2}\right)$ remained vertical, and changes in the state of stress consisted of variations in the trend of maximum and minimum principal stress axes $\left(S_{1}\right.$ and $\left.S_{3}\right)$ and small variations in the value of the relative stress magnitudes $(\phi)$. In general, the stress state in the ECSZ has $S_{1}$ trending east of north and $\phi=0.43$ to 0.65 , suggesting that the ECSZ is a moderate stress refractor and the style of faulting is transtensional.

South of the Pinto Mountain fault, in the region of the 1992 Joshua Tree earthquake, the stress state determined from the 1981 to 1991 background seismicity changed on 23 April and again on 28 June 1992. In the central zone, $S_{1}$ rotated from $\mathrm{N} 14^{\circ} \pm 5^{\circ} \mathrm{E}$ to $\mathrm{N} 28^{\circ} \pm 5^{\circ} \mathrm{E}$ on 23 April and back again to N16 $\pm 5^{\circ} \mathrm{E}$ on 28 June. Thus, the Landers mainshock in effect recharged some of the shear stress in the region of the $M_{W} 6.1$ Joshua Tree earthquake.

Comparison of the state of stress before and after 28 June 1992, along the Landers mainshock rupture zone, showed that the mainshock changed the stress orientation. The $S_{1}$ trend rotated $7^{\circ}$ to $20^{\circ}$ clockwise and became progressively more fault normal from south to north. Along the Emerson-Camp Rock faults, the variation was so prominent that the focal mechanisms of aftershocks could not be fit by a single deviatoric stress tensor. The complex distribution of $P$ and $T$ axes suggests that most of the uniform component of the applied shear stress along the northern part of the rupture zone was released in the mainshock.

The San Bernardino Mountains region of the $M_{W} 6.2$ Big Bear earthquake has a distinctively different state of stress, as compared to the Landers region, with $S_{1}$ trending $\mathrm{N}^{\circ} \pm 5^{\circ} \mathrm{W}$. This region did not show any significant change in the state of stress following the $1992 M_{W} 6.2$ Big Bear sequence.
\end{abstract}

Introduction

The $1992\left(M_{W} 6.1,7.3\right.$, and 6.2) Landers earthquake sequence (Fig. 1) clearly changed the state of stress in southern California. These changes, however, are difficult to interpret, in part because the background stress state has only been determined in limited places, such as along the San Andreas fault (Jones, 1988), in the Anza Seismic Gap along the San Jacinto fault (Hartse et al., 1994), and in the Los Angeles basin (Hauksson, 1990). Zoback et al. (1987) and Mount and Suppe (1992) have suggested that the stress state in southern California is controlled by the San Andreas fault zone. In their inter- pretation, the San Andreas fault zone is a weak fault (which in an extreme case can be thought of as a free surface) and acts as a stress refractor. Such a weak San Andreas fault could control the stress out to a distance of $100 \mathrm{~km}$ on either side (Zoback et al., 1987).

The weak fault model was developed initially for the San Andreas fault in central California, where stress directions, geological, and geophysical data are consistent with the weak fault interpretation (Mount and Suppe, 1987). Several lines of evidence, however, suggest that the weak fault model may not apply as well to the San 
Andreas fault in southern California. For instance, Sonder (1990) pointed out that the maximum principal stress axis $\left(S_{1}\right)$ trends in the Transverse Ranges are oriented $23^{\circ}$ more northerly as compared to $S_{1}$ trends in most other places in central and southern California. She modeled these as being related to the negative buoyancy density anomaly beneath the Transverse Ranges and not controlled exclusively by the San Andreas fault. Jones (1988) showed from stress inversions of local earthquakes occurring near the San Andreas fault that the $S_{1}$ in general is oriented $43^{\circ}$ to $68^{\circ}$ north of the strike of the San Andreas fault, which only partially supports the weak fault hypothesis. Thus, the state of stress and the overall importance of the weak San Andreas fault in southern California remains poorly understood.

In addition to weak faults and density anomalies in the lithosphere, the state of stress is also affected by coseismic stress changes or the time since the last major earthquake. The $1989 M_{S} 7.1$ Loma Prieta earthquake released most of the shear stress applied to that segment of the San Andreas fault system (Michael et al., 1990; Beroza and Zoback, 1993; Zoback and Beroza, 1993). Beroza and Zoback (1993) also suggested that the remaining stress field was a fault-normal uniaxial compressive field, which caused a great diversity of aftershock focal mechanisms. Looking farther away from the mainshock rupture, Reasenberg and Simpson (1992) showed that the changes in the static stress field affected the rate of background seismicity up to 80 to $100 \mathrm{~km}$ away from the rupture zone of the Loma Prieta earthquake. Similarly, several attempts have been made to predict stress changes through modeling of the stress drop of the Landers mainshock and its effect on major faults in southern California (Harris and Simpson, 1992; Jaume and Sykes, 1992; Stein et al., 1992).

To contribute to the determination of both the regional static stress field and the co-seismic stress changes, this article focuses on determining the state of stress before and after the 1992 Joshua Tree, Landers, and Big Bear earthquakes in the immediate vicinity of the surface

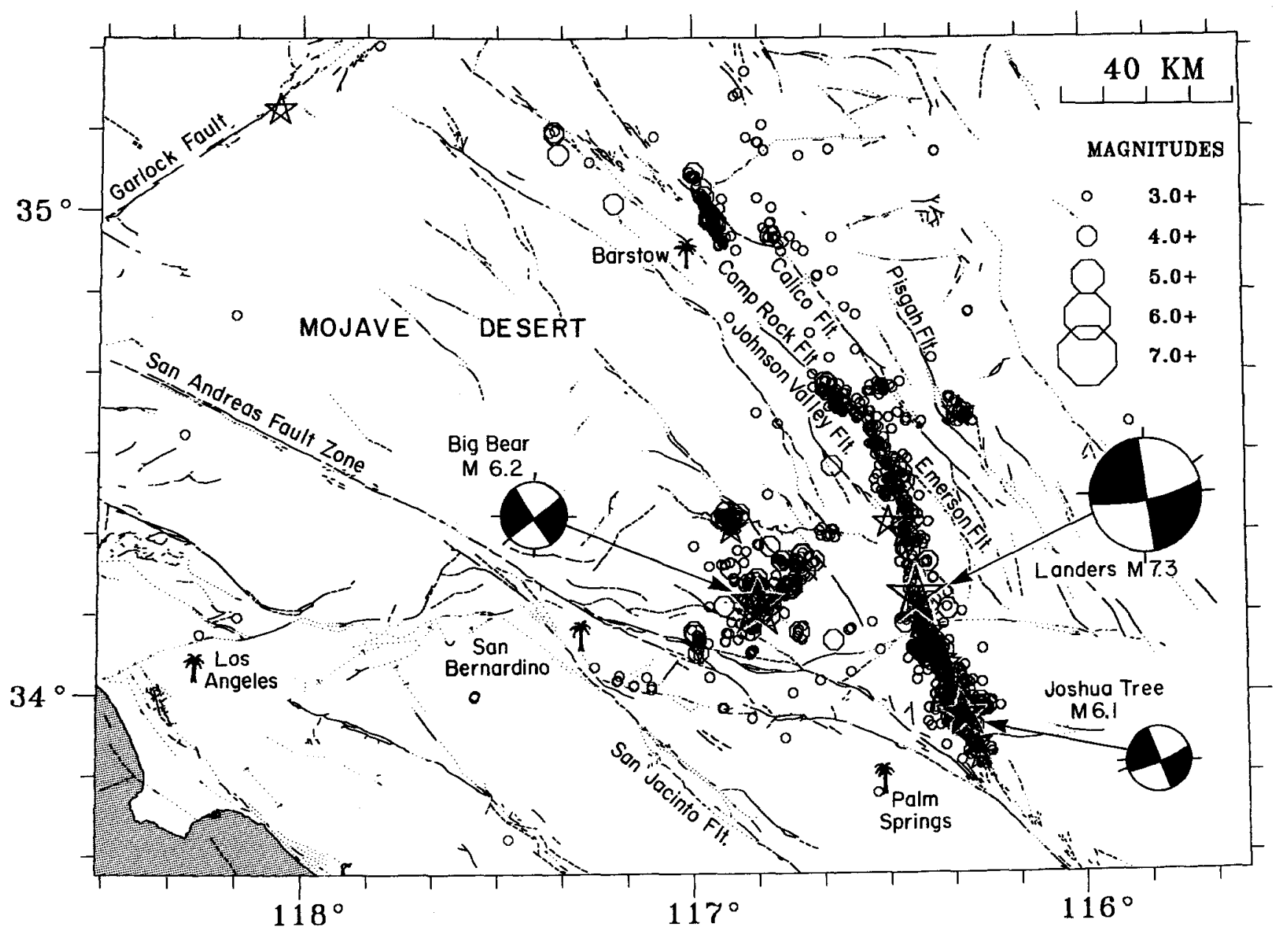

Figure 1. Map of southern California including the eastern California shear zone (Dokka and Travis, 1990), showing major faults from Jennings (1975), and the locations and first-motion focal mechanisms of the $1992 M_{W} 6.1$ Joshua Tree, $M_{W} 7.3$ Landers, and $M_{W} 6.2$ Big Bear earthquakes and aftershocks of $M \geq 3$. Aftershocks of $M \geqq 5$ are shown as stars. Palm trees indicate locations of cities. 
rupture (Fig. 1). These three events were preceded by background seismicity and caused abundant aftershock activity in the Eastern California Shear Zone (ECSZ), which is used to calculate focal mechanisms and to determine the state of stress. The earthquake data set from the 1992 Landers sequence consists of more than 60,000 recorded earthquakes in 1992. This article gives a preview of possible stress studies and will undoubtedly be followed by numerous more detailed articles. This article is a sequel to the article by Hauksson et al. (1993) that presented detailed seismicity and focal mechanism plots from this sequence.

\section{Data and Approach}

Earthquake data recorded by the California Institute of Technology/U.S. Geological Survey (CIT/USGS) Southern California Seismic Network were analyzed in this study. Two velocity models and a corresponding set of station delays from Hauksson et al. (1993) were used to calculate hypocenters and take-off angles in this study. Almost 3000 single-event, lower-hemisphere focal mechanisms were determined from $P$-wave first-motion polarities using a grid-searching algorithm and computer programs developed by Reasenberg and Oppenheimer (1985). Focal mechanisms were determined for earthquakes from the following: (1) $1975 \mathrm{Gal}-$ way Lake sequence; (2) 1979 Homestead Valley sequence; (3) background seismicity from 1981 to 1991; (4) 1992 Joshua Tree sequence; and (5) 1992 Landers sequence, including the Barstow and Big Bear sequences.

A stress inversion technique developed by Michael (1984) was used to invert for the state of stress. The inversion assumes that the regional stress field is a constant tensor, that all slip events are independent, and that the magnitude of the tangential traction (or $\mid T$ ) applied to each fault plane is similar. The third assumption is equivalent to assuming that $\mid T=1$, because only relative stress magnitudes can be calculated. The inversion minimizes the misfit angle $(\beta)$ between the directions of the common shear stress on the fault planes and the observed slip direction on each plane determined from the focal mechanism. The inversion solves for the orientation of the three principal stress axes and the $\phi$ value, a measure of the relative magnitude of the principal stresses defined as

$$
\phi=\left(S_{2}-S_{3}\right) /\left(S_{1}-S_{3}\right),
$$

where $S_{1}, S_{2}$, and $S_{3}$ are the maximum, intermediate, and minimum compressive principal stress axes.

One plane must be selected from each focal mechanism as the actual fault plane (Michael, 1987a). In general, north to northwest striking, right-lateral planes in strike-slip focal mechanisms were chosen. North-dip- ping planes in the reverse or thrust mechanisms were chosen because these are assumed to be more consistent with the geological deformation than the south-dipping planes (Dokka and Travis, 1990). The planes indicating faulting down to the south or east were chosen for the normal faulting mechanisms. In general, the choice of planes does not affect the results of the stress inversion, but may affect the size of the $95 \%$ confidence region (Michael, 1987a).

Although the geological information makes it possible to select many planes correctly, other planes may be picked incorrectly. This is accounted for in the bootstrap technique used to calculate the confidence limits for the orientations by assuming that a certain percentage of the planes are picked incorrectly (Michael, 1987b). For most of the inversions, presuming $10 \%$ of the planes were picked incorrectly gives the average $95 \%$ confidence intervals of about $10^{\circ}$ for the $S_{1}$ trend. The largest $95 \%$ confidence intervals of $20^{\circ}$ to $25^{\circ}$ are obtained for $S_{1}$ trends from small data sets, with less than 30 focal mechanisms. In this article, the error bars represent the 95\% confidence limits.

The average uncertainties in the strike, dip, and rake of the focal mechanisms are $10^{\circ}, 18^{\circ}$, and $20^{\circ}$, respectively. The results of the inversion provide average misfit angles $(\beta)$ generally in the range of $17^{\circ}$ to $44^{\circ}$ (Table 1). According to Michael (1991), the $\beta$ values of up to $44^{\circ}$, given the uncertainties in the focal mechanisms, provide a valid fit to a single deviatoric stress tensor. For the aftershocks located along the Emerson-Camp Rock faults, however, the misfit exceeds $70^{\circ}$, meaning they could not be fit by a single deviatoric stress tensor. The standard deviation of $\phi$ ranged from 0.11 to 0.26 .

In all cases, the $S_{2}$ is vertical, and the relative magnitude of the stresses $(\phi)$ ranges from 0.43 to 0.90 . The $\phi$ values of 0.4 to 0.6 and vertical $S_{2}$ indicate that all the three principal stresses are different, and the style of faulting is predominantly strike slip. Similarly, the $\phi$ values of 0.7 to 1 and vertical $S_{2}$ indicate that the magnitude difference between $S_{1}$ and $S_{2}$ has decreased, and the style of faulting is strike slip mixed with normal faulting.

\section{Results}

Most of the stress changes caused by the occurrence of the $M_{W} 6.1$ Joshua Tree and the $M_{W} 7.31992$ Landers earthquakes consist of variations in the trend of $S_{1}$ and small variations in the value of $\phi$, while $S_{2}$ remains vertical (Table 1). To facilitate description of spatial and temporal variations, the region is divided into the following four main areas: (1) Little San Bernardino Mountains; (2) Landers zone; (3) Barstow region; and (4) San Bernardino Mountains. 


\section{Little San Bernardino Mountains}

The Little San Bernardino Mountains (LSBM) are defined here as the region between the Pinto Mountain fault to the north, the San Andreas fault on the southwest side, and an eastern boundary formed by a north-south line $116^{\circ} \mathrm{W}$ (the approximate eastern boundary of the Joshua Tree aftershock zone) extending from Indio to the Pinto Mountain fault (Fig. 2). To determine the spatial distribution of stress within the LSBM, the slip vectors from the focal mechanisms were grouped into three subregions. The first subregion (Blue Cut) is south of the 1992 mainshock, extending to the San Andreas fault north of Indio. The second subregion (Joshua Tree) extends $10 \mathrm{~km}$ to the north from the mainshock epicenter. The third subregion (Eureka Peak) extends from the north end of the Joshua Tree mainshock rupture to the Pinto Mountain fault. These three subregions experienced background seismicity from 1981 to 1991 and intense aftershock activity during 1992.

Stress from 1981 to 1991 Seismicity. Focal mecha- nisms of the background seismicity from 1981 to 1991 were used to determine the state of stress before 1992 in the LSBM (Fig. 2a). This background seismicity consisted of scattered activity and several smaller clusters, such as a swarm of earthquakes in 1985. In general, this background seismicity coincided spatially with the 1992 aftershocks.

Overall, the results of the stress inversion showed that the $S_{1}$ trended east of north, $\mathrm{N} 24^{\circ} \pm 5^{\circ} \mathrm{E}$ in the Blue Cut region, $\mathrm{N} 14^{\circ} \pm 5^{\circ} \mathrm{E}$ in the Joshua Tree region, and $\mathrm{N} 3^{\circ} \pm 10^{\circ} \mathrm{E}$ in the Eureka Peak region (Fig. 2a). The stress state is better constrained in the Blue Cut and the Joshua Tree regions; the stress state in the Eureka Peak region has large 95\% confidence limits because of the small number of mechanisms available. In spite of this large $95 \%$ confidence interval, this stress state is statistically different from the ones to the south. The earthquakes that contribute to it are located to the northwest and may be influenced by the state of stress in the San Bernardino Mountains, which is discussed later. Jones (1988) and Williams et al. (1990) found a similar stress field, with $S_{1}$ trending about $\mathrm{N} 20^{\circ} \mathrm{E}$ in the LSBM region.

Table 1

State of Stress in the Eastern California Shear Zone

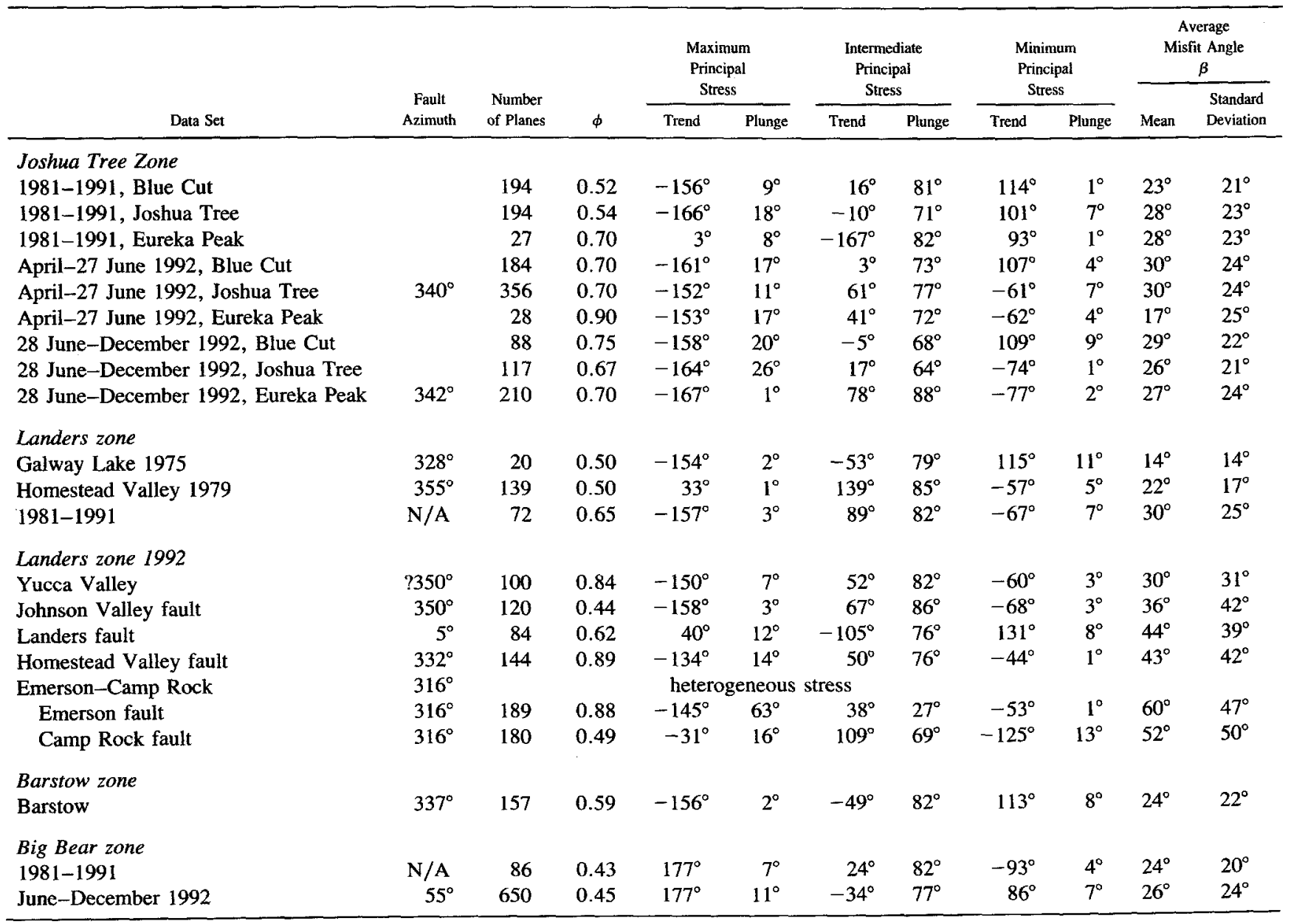


Because these stress measurements are an average over a decade, we implicitly presume that the stress did not change significantly during that time period.

The style of faulting varies among the three regions, with the Blue Cut and Joshua Tree regions having north to north-northwest striking mostly strike-slip faulting with $\phi=0.52 \pm 0.15$ and $\phi=0.54 \pm 0.17$, while the Eureka Peak region has a mixed strike-slip and normal faulting regime with $\phi=0.7 \pm 0.17$. The LSBM are not dominated by one fault structure, and many small strike-slip faults exist in the region with different strikes (Dibblee, 1967; Rymer, 1992).

Stress from 23 April to 27 June 1992 Aftershocks. The 23 April 1992 Joshua Tree mainshock was followed by more than 6000 recorded aftershocks (Hauksson et al., 1993) (Fig. 2b). The stress state that was determined from focal mechanisms of $\mathbf{5 7 0}$ of these events is similar in the Blue Cut, Joshua Tree, and Eureka Peak regions, with $S_{1}$ trending $\mathrm{N} 18^{\circ} \pm 5^{\circ} \mathrm{E}, \mathrm{N} 28^{\circ} \pm 5^{\circ} \mathrm{E}$, and $\mathrm{N} 26^{\circ} \pm 12^{\circ} \mathrm{E}$, respectively. In the Joshua Tree area, the $S_{1}$ trend is $48^{\circ}$ clockwise from the fault strike, inferred from the nodal plane of the mainshock focal mechanism (Fig. 1). In all three regions, $\phi$ increased by 0.2 from $0.52 \pm 0.15$, $0.54 \pm 0.17$, and $0.7 \pm 0.17$ to $0.7 \pm 0.17,0.7 \pm 0.18$, and $0.9 \pm 0.12$, respectively. A larger $\phi$ means that $S_{1}$ is closer to the vertical $S_{2}$ in magnitude, which is assumed to be constant.

Stress from 28 June to 31 December 1992 Aftershocks. The $M_{W} 7.3$ Landers mainshock caused numerous aftershocks in the Eureka Peak region and reactivated aftershock activity in the Joshua Tree and Blue Cut regions (Hauksson et al., 1993).

The stress states determined from the aftershocks following 28 June show that the three subregions now have $S_{1}$ trends $\mathrm{N} 22^{\circ} \pm 7^{\circ} \mathrm{E}, \mathrm{N} 16^{\circ} \pm 5^{\circ} \mathrm{E}$, and $\mathrm{N} 13^{\circ} \pm$ $5^{\circ} \mathrm{E}$, respectively (Fig. $2 \mathrm{c}$ ). The $\phi$ value decreased only in the Eureka Peak region, from $\phi=0.9 \pm 0.12$ to $\phi$ $=0.7 \pm 0.16$, returning to its pre-Joshua Tree value. The $S_{1}$ trend of $\mathrm{N}^{\circ} 3^{\circ}$ to $22^{\circ} \mathrm{E}$ represents a significant ro-

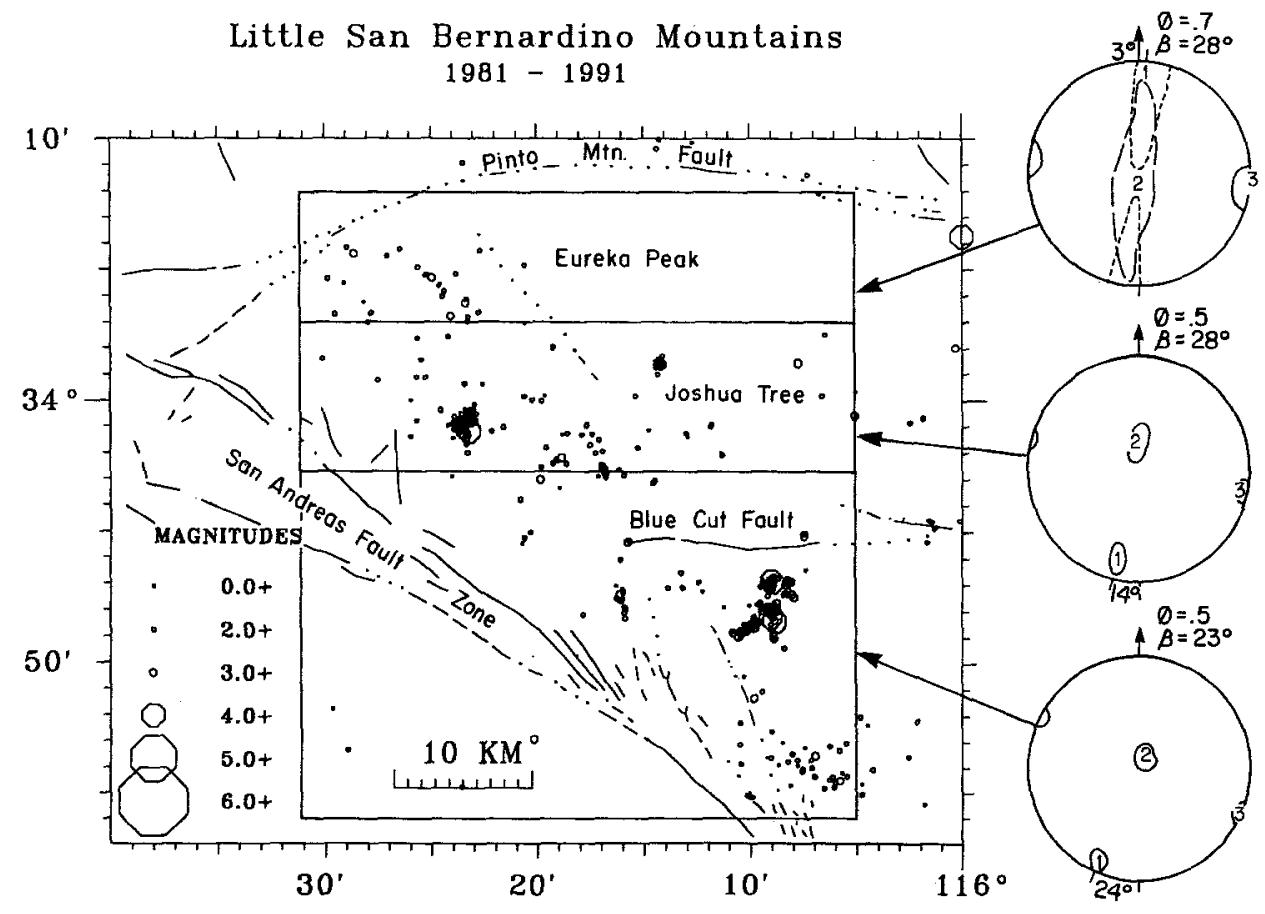

(a)

Figure 2. Seismicity and stress inversion results for the Little San Bernardino Mountains. The orientations of the principal stress axes with $95 \%$ confidence areas, determined assuming that $10 \%$ of the planes were picked incorrectly, are indicated with solid, heavy dashed, or light dashed lines; 1,2 , and 3 are the maximum, intermediate, and minimum principal stress axes; $\beta$ is the misfit angle; and $\phi$ is the relative stress magnitude. (a) The 1981 to 1991 background seismicity and the stress inversion results for the Blue Cut, Joshua Tree, and Eureka Peak subregions. (b) The 23 April to 27 June 1992 Joshua Tree aftershocks. (c) The 28 June to 31 December 1992 Landers aftershocks. 
Little San Bernardino Mountains

22 April - 27 June 1992

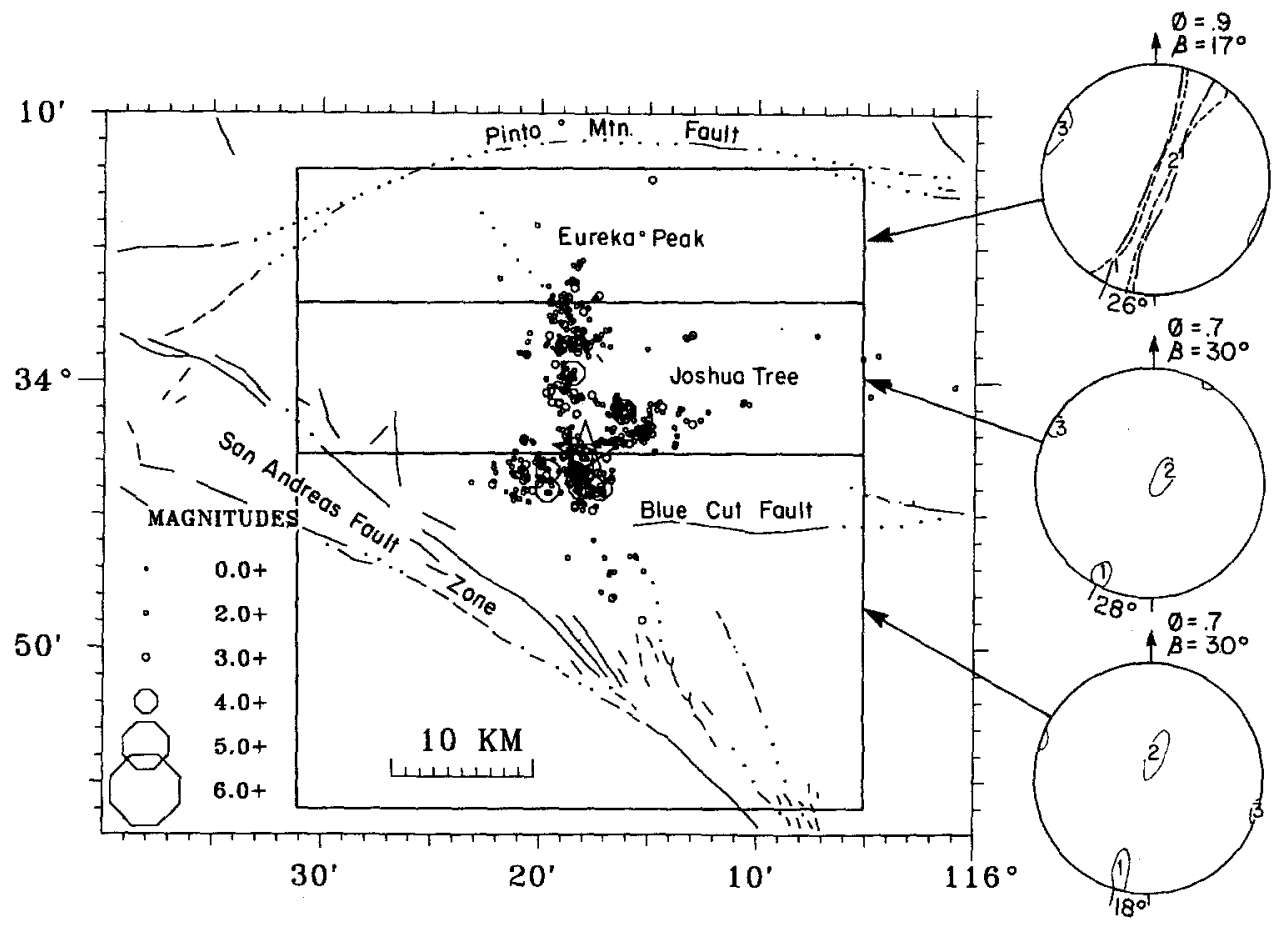

(b)

Little San Bernardino Mountains 28 June - 31 December 1992

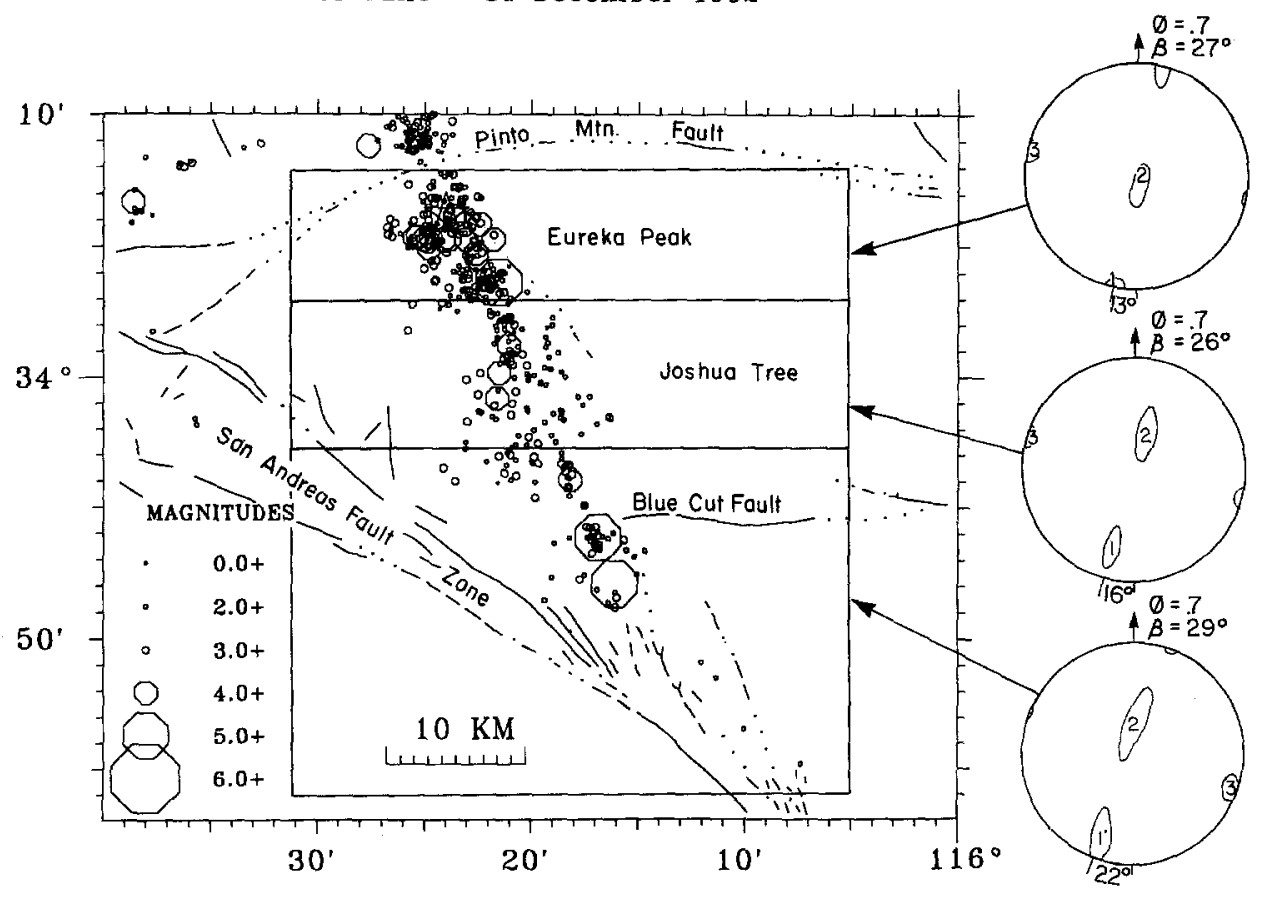

(c)

Figure 2-Continued 
tation of the $S_{1}$ back to the stress state prior to 23 April 1992.

In summary, the stress state from the 1981 to 1991 background seismicity changed on 23 April and 28 June 1992. The azimuth of $S_{1}$ for the three subregions is shown as a function of time in Figure 3 . The change is best
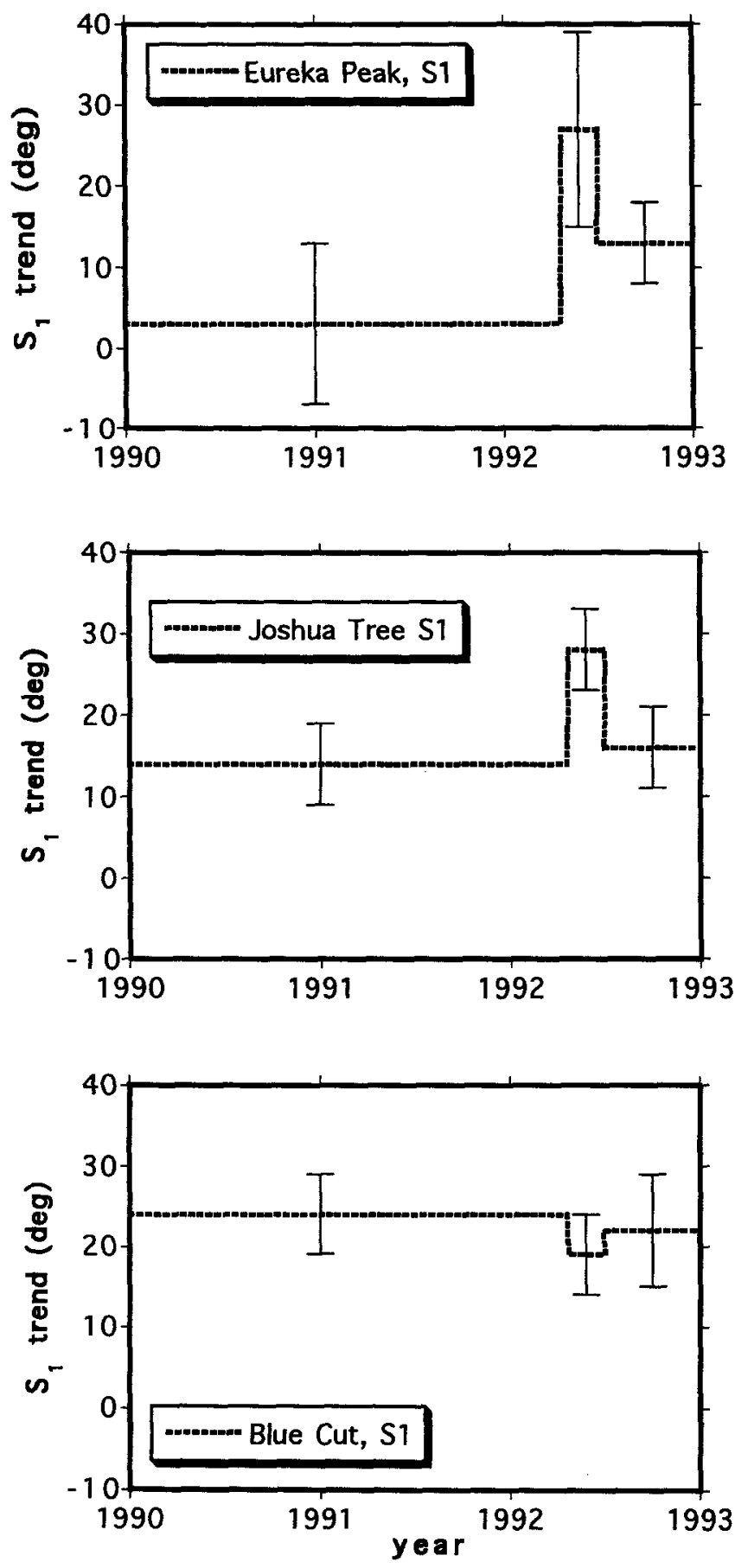

Figure 3. The trend of $S_{1}$ versus time for the three regions in the Little San Bernardino Mountains: Eureka Peak, Joshua Tree, and Blue Cut. Error bars correspond to the $95 \%$ confidence regions. measured in the Joshua Tree region, where $S_{1}$ rotated from $\mathrm{N} 14^{\circ} \pm 5^{\circ} \mathrm{E}$ to $\mathrm{N} 28^{\circ} \pm 5^{\circ} \mathrm{E}$ on 23 April and back again on 28 June to $\mathrm{N} 16^{\circ} \pm 5^{\circ} \mathrm{E}$ (Fig. 3). Thus, on 28 June, the Landers mainshock likely recharged some of the shear stress on vertical planes in the region of the $M_{W}$ 6.1 Joshua Tree earthquake. It is less likely that these changes in stress are caused by a spatially heterogeneous stress field, although the details of the spatial distribution of earthquake activity are slightly different during each time period (Fig. 2). Although the state of stress changed twice in 1992, the style of faulting remained essentially strike slip on north to northwest striking planes with a varying component of normal faulting. The observed increase of $\phi$ in April is interpreted as a decrease in the magnitude of $S_{1}$ because of the stress release in the earthquake.

To test the significance of the $S_{1}$ rotations, we repeated the stress inversion for the whole LSBM region. The rotation of the $S_{1}$ trend is also significant for the whole data set, with $S_{1}$ trending $N 18^{\circ} \pm 5^{\circ} \mathrm{E}, \mathrm{N} 25^{\circ} \pm$ $5^{\circ} \mathrm{E}$, and $\mathrm{N} 15^{\circ} \pm 5^{\circ} \mathrm{E}$ during the time periods 1981 to 1992, April to June 1992, and July to December 1992, respectively. The data set from 1981 to 1992 was further subdivided into two data sets from 1981 to 1987 and 1987 to 1992 to test for intrinsic variations in the $S_{1}$ trend. The $S_{1}$ trend was $\mathrm{N} 18^{\circ} \pm 5^{\circ} \mathrm{E}$ and $\mathrm{N} 19^{\circ} \pm 5^{\circ} \mathrm{E}$, respectively. This suggests that the background variations in the state of stress in the LSBM are small during the 1981 to 1992 time period.

\section{The Landers Zone}

The Landers earthquake ruptured five different fault segments with a total length of $85 \mathrm{~km}$ and caused aftershocks over a much larger region (Sieh et al., 1993). The Landers zone is defined here as the region of aftershocks in the immediate vicinity of the $M_{W} 7.3$ Landers mainshock rupture zone, extending from the Pinto Mountain fault to the end of the surface rupture, where the Emerson and the Camp Rock faults merge (Fig. 1).

Stress from 1981 to 1991 Seismicity. The state of stress near the Landers rupture zone in the 2 decades before the $M_{W} 7.3$ Landers earthquake has been determined from focal mechanisms of earthquakes from the 1975 Galway Lake and 1979 Homestead Valley sequences, and the background seismicity from 1981 to 1991 (Fig. 4). Both the 1975 Galway Lake and the 1979 Homestead Valley sequences occurred adjacent to the Landers rupture zone. Focal mechanisms from these sequences are useful indicators for the state of stress near the rupture zone prior to the earthquake. Although the background seismicity is somewhat more diffuse, with more events located to the south, near the Johnson Valley fault, than to the north along the Emerson-Camp Rock faults, focal mechanisms from it are assumed to represent a reasonable av- 
erage stress state during the decade before the occurrence of the Landers earthquake.

All three data sets yield similar deviatoric stress tensors within the $95 \%$ confidence limits. These stress states have $S_{1}$ trending $\mathrm{N} 26^{\circ} \pm 10^{\circ} \mathrm{E}, \mathrm{N} 33^{\circ} \pm 5^{\circ} \mathrm{E}$, and $\mathrm{N} 22^{\circ}$ $\pm 5^{\circ} \mathrm{E}$ for focal mechanisms from Galway Lake, Homestead Valley, and the 1981 to 1991 background seismicity, respectively. These three independent measurements of the $S_{1}$ trend are consistent and show that prior to the Landers mainshock spatial stress variations were small. This stress state implies that the angle between the maximum principal stress and orientations of faults that ruptured in the 1992 Landers mainshock ranged from $37^{\circ}$ to $58^{\circ}$. For all three data sets, the $\phi=0.5$ to 0.65 , indicating a strike-slip stress state consistent with the faulting reported in the Landers mainshock (Sieh et al., 1993; Hauksson et al., 1993) (Fig. 4).

Stress from 28 June 1992 Aftershocks. To separate regions that could have different states of stress, we have divided the Landers zone into the following five separate subregions: (1) Yucca Valley to the south of the mainshock epicenter; (2) the Johnson Valley fault, to the north of the mainshock epicenter; (3) the Landers fault; (4) the Homestead Valley fault; and (5) the Emerson-Camp Rock faults. This division approximately matches the different surficial faults that ruptured in the mainshock (Fig. 5).

South of the mainshock epicenter, in the Yucca Valley subregion, $S_{1}$ trends $\mathrm{N} 30^{\circ} \pm 3^{\circ} \mathrm{E}$ with $\phi=0.84 \pm$ 0.17 , indicating strike slip and normal faulting. In the Johnson Valley fault subregion, where the Landers mainshock epicenter is located, $S_{1}$ trends $\mathrm{N} 22^{\circ} \pm 7^{\circ} \mathrm{E}$ and the style of faulting is strike slip with $\phi=0.44 \pm$ 0.2 . The $S_{1}$ trend did not change significantly in either subregion from the trend during 1981 to 1991 as a result of the mainshock.

The Landers fault, which formed the step-over from the Johnson Valley fault to the Homestead Valley fault, is the only fault segment that strikes east of north $\left(\mathrm{N} 5^{\circ} \mathrm{E}\right)$. The $S_{1}$ trends $\mathrm{N} 40^{\circ} \mathrm{E}$ and the style of faulting is strike slip with $\phi=0.62 \pm 0.22$. Compared to the 1979 Homestead Valley $S_{1}$ trend, the $S_{1}$ trend has rotated clockwise by $7^{\circ}$ because of the Landers earthquake. This rotation is not significant at the $95 \%$ confidence level.

As an example of the data used in the stress inversions, focal mechanisms and a $P$ and $T$ axes plot for aftershocks along the intersection of the Landers fault with the Johnson Valley and the Homestead Valley faults are shown in Figures $6 \mathrm{a}$ and $6 \mathrm{~b}$. The focal mechanisms are diverse, with strike-slip, normal, and thrust mech-

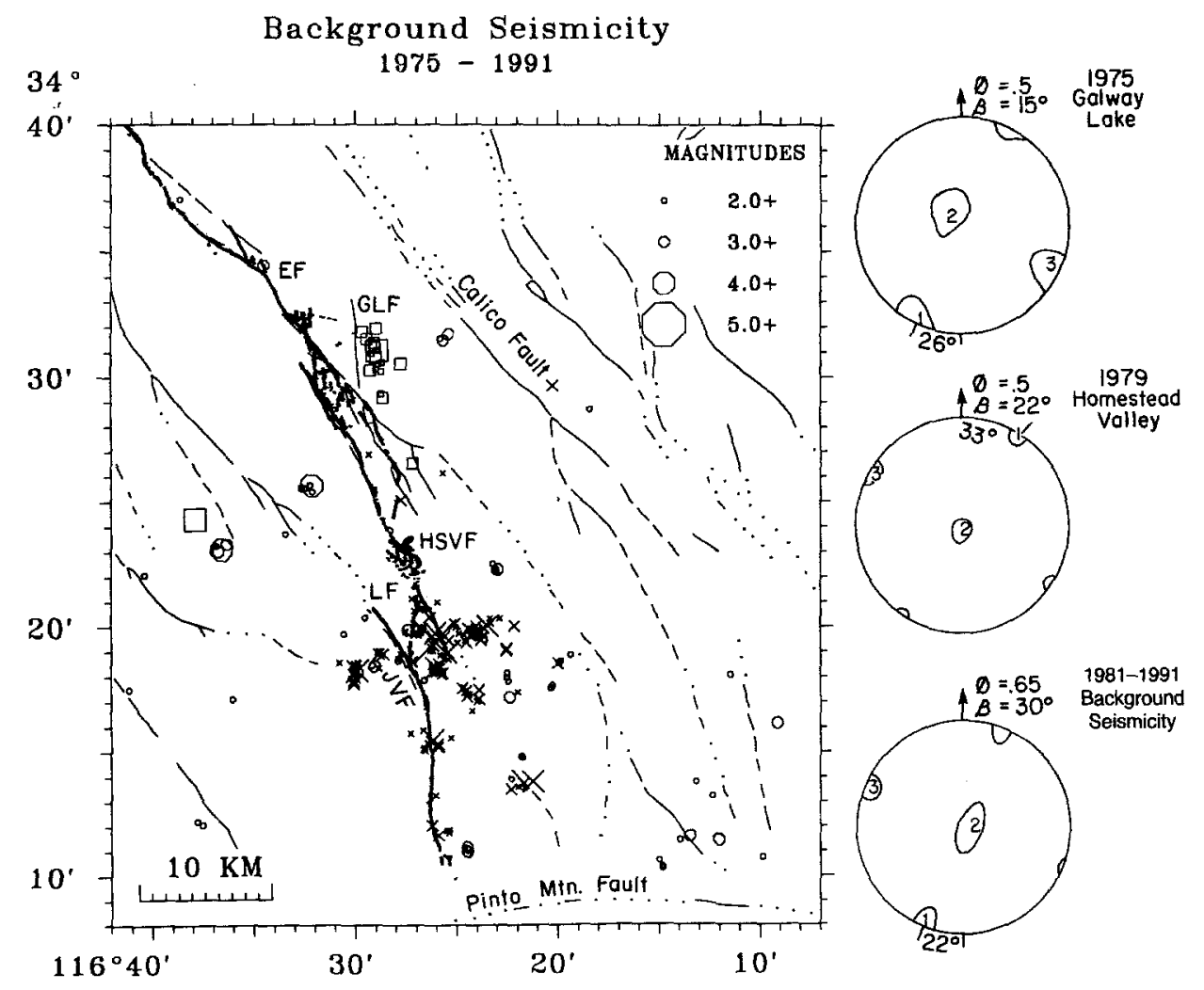

Figure 4. Results from the stress inversion of focal mechanisms from the following: (1) Galway Lake 1975, shown with square symbols; (2) Homestead Valley 1979, shown with $x$ symbols; and (3) background seismicity near Landers 1981 to 1991, shown with circles (see also Fig. 2 for labeling of stresses). 
anisms mixed together. The majority of the $P$ axes, however, are uniformly distributed, with trends from north-northeast to northeast, indicating some regional consistency in the stress directions.

The stress state in the Homestead Valley subregion has $S_{1}$ trending $N 46^{\circ} \mathrm{E}$ and the style of faulting is a mixture of strike slip and normal with $\phi=0.89 \pm 0.22$. In comparison to the $S_{1}$ trend determined from the 1975 Galway Lake sequence, the $S_{1}$ trend has rotated clockwise by $20^{\circ}$. This change is significant at the $95 \%$ confidence level.

Farther to the north, in the Emerson-Camp Rock subregion, the stress state cannot be fit with a single deviatoric stress tensor using the techniques of Michael

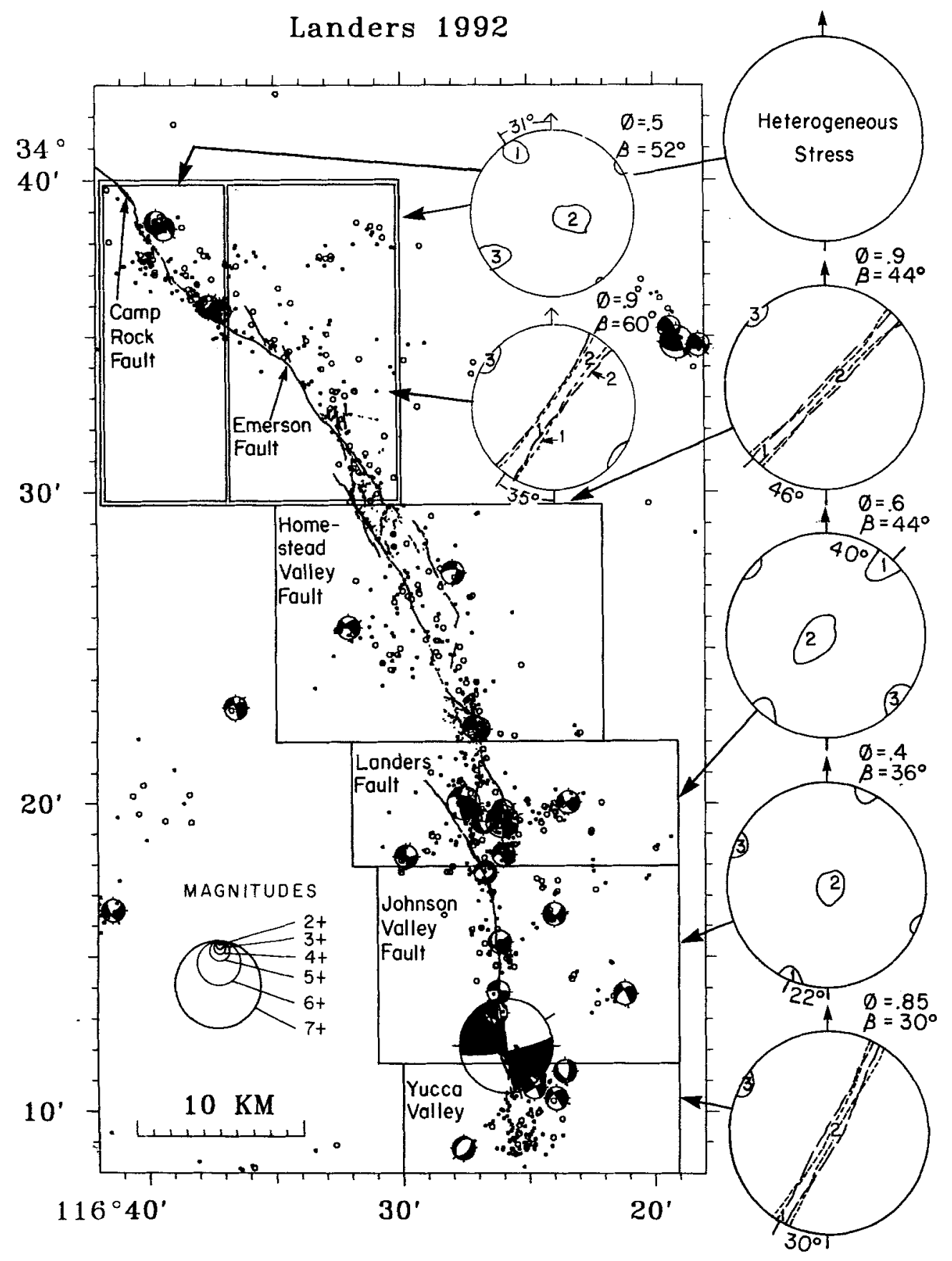

Figure 5. Results from the stress inversion of focal mechanisms from the Landers zone (see also Fig. 2 for labeling of stresses). Lower-hemisphere singleevent focal mechanisms for $M>5$ events are also shown. Compressional quadrants are shaded with lines. The stress inversion for the Emerson-Camp Rock region was performed both for the whole region and the two subregions, as indicated by the rectangles. 
$(1984,1991)$. Slip in the Landers mainshock was greatest $(4$ to $6.5 \mathrm{~m}$ ) in this region (Sieh et al., 1993; Wald and Heaton, 1994), indicating that the mainshock may have released most of the uniform component of the applied shear stress, forming a complex fault-normal stress state.

To explore further the state of stress along the Emerson-Camp Rock faults, the region was subdivided into two smaller subregions. Both stress inversions yield $\beta$ values larger than $47^{\circ}$, indicating that the misfit is unreasonably large. The subregion on the east mostly contains aftershocks along the Emerson fault. Here, the $S_{1}$ trends $\mathrm{N} 35^{\circ} \pm 5^{\circ} \mathrm{E}$ and forms an angle of $80^{\circ}$ with the strike of the Emerson fault. The high $\phi=0.88 \pm 0.26$ indicates that the style of faulting is a mixture of strike slip and normal. The western subregion contains aftershocks in the overlap between the Emerson and Camp Rock faults. The stress state here is radically different from elsewhere along the Landers rupture zone. The $S_{1}$ trends $\mathrm{N} 31^{\circ} \pm 7^{\circ} \mathrm{W}$, showing that the two horizontal maximum principal stresses have flipped. These rapid spatial variations in the state of stress suggest that along this part of the rupture zone, the two horizontal stresses are of similar magnitude.
The aftershock focal mechanisms are diverse, with right-lateral mechanisms mixed in with left-lateral mechanisms on north-south trending planes. These coexist with normal and thrust mechanisms on northerly or westerly trending planes (Fig. 7a). The $P$ axes show broad scatter with at least two poorly defined distributions with north-northeast to northeast trending axes and northnorthwest to northwest trending axes (Fig. 7b). If the uniform component of the shear stress was released, then the remaining part is very heterogeneous. Furthermore, the final stress state can either be interpreted to have $S_{1}$, $S_{2}$, and $S_{3}$ of similar magnitudes, or fault normal compression, which results in a change in the $S_{1}$ trend of about $20^{\circ}$. This finding of less residual shear stress in the north is consistent with the observation of fewer large aftershocks along the northern part (Hauksson et al., 1993).

In summary, the azimuth of the $S_{1}$ pre- and postLanders values and the strike of the respective fault segments are shown in Figure 8. The most noticeable change occurred to the north along the Landers, Homestead Valley, and Emerson-Camp Rock faults. Much of the uniform component of the shear stress has been removed,

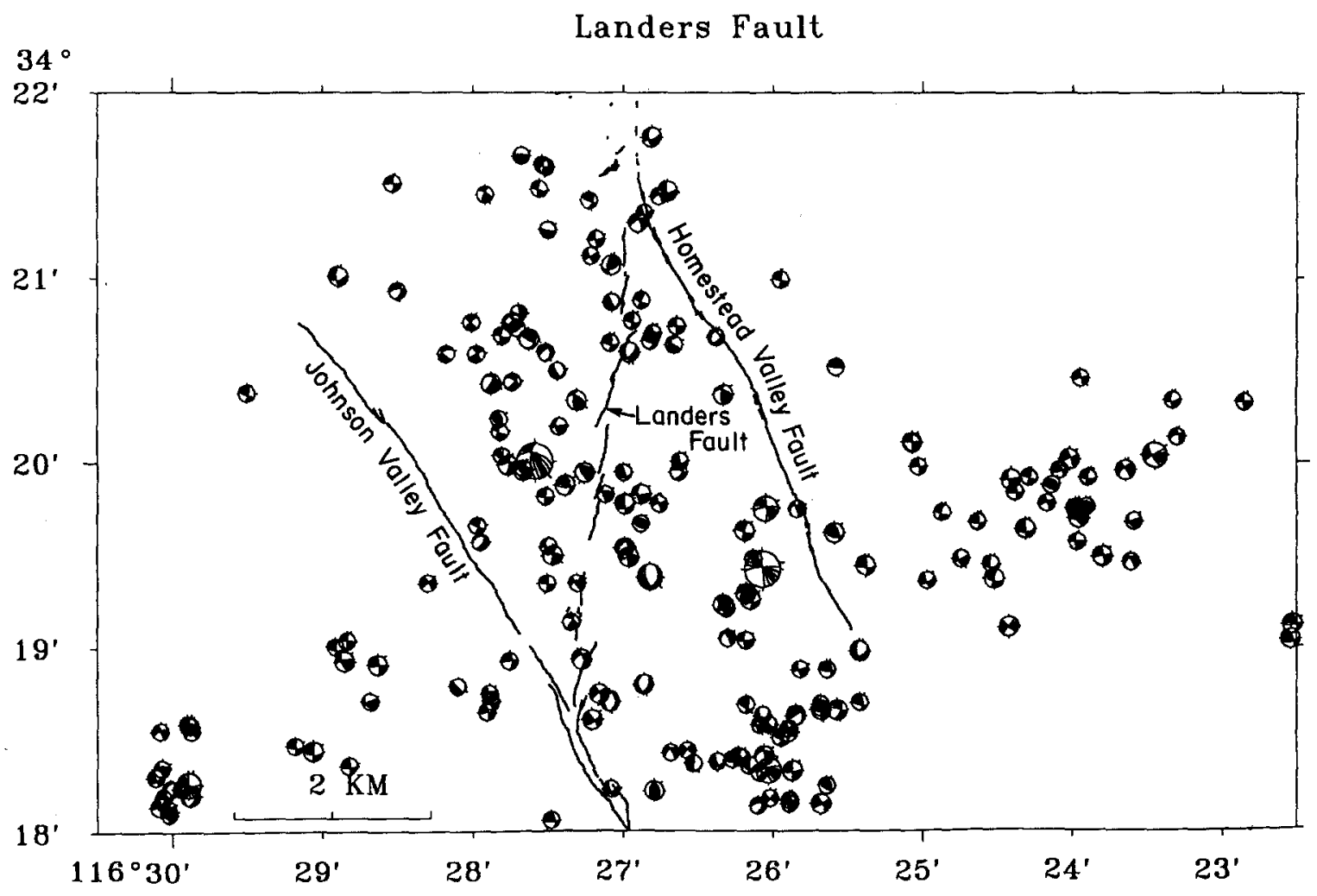

(a)

Figure 6. (a) Single-event lower-hemisphere focal mechanisms and (b) $P$ and $T$ axes of Landers aftershocks (June to December 1992) from the Landers fault area. 


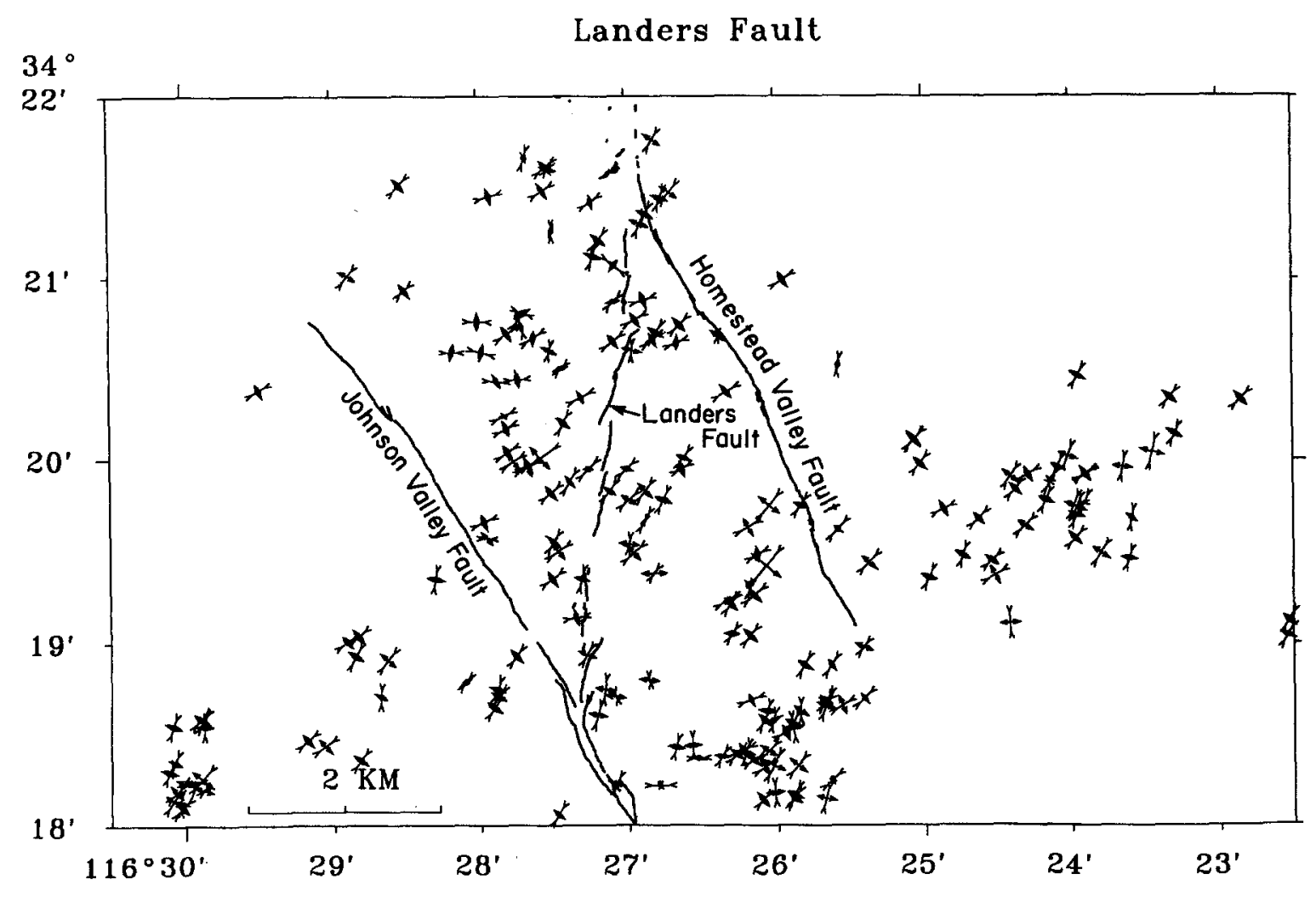

(b)

Figure 6-Continued

making the trend of $S_{1}$ more fault normal and making it more similar to the magnitudes of the other stresses.

\section{Barstow Region}

The Barstow aftershock cluster that began within hours of the Landers mainshock did not occur on a surficially mapped fault. It formed a $20-\mathrm{km}$-long alignment of epicenters striking $\mathrm{N} 23^{\circ} \mathrm{W}$, approximately centered on the trace of the Calico fault. It was energetic during the first weeks following the 28 June $M_{W} 7.3$ Landers earthquake but showed a normal aftershock decay behavior (Hauksson et al., 1993). The maximum earthquake size within the swarm was about $M 4.8$, and hence no significant stress release occurred within the region of the swarm.

The state of stress for the whole swarm (Fig. 9) has $S_{1}$ trending $\mathrm{N} 24^{\circ} \pm 5^{\circ} \mathrm{E}$ and forming a $47^{\circ}$ difference in trend with the average azimuth of the swarm. The 1981 to 1991 background seismicity had a similar $S_{1}$, trending $\mathrm{N} 22^{\circ} \pm 5^{\circ} \mathrm{E}$, again implying that any stress change caused by the Landers mainshock in the region of the Barstow swarm was small.

The clear strike-slip stress state with $\phi=0.59 \pm$ 0.15 is consistent with the major strike-slip faults, including the Calico fault, that pass through the region.
The mapped strike-slip faults in the region, such as the Calico fault, trend more westerly, so the difference in trend with $S_{1}$ is $60^{\circ}$ to $70^{\circ}$. That the Barstow cluster did not occur on the Calico fault but, rather, on an unmapped fault structure with a strike difference of $10^{\circ}$ to $20^{\circ}$, implies that the Calico fault is not preferentially oriented compared to the present stress state.

\section{San Bernardino Mountains}

In the San Bernardino Mountains, scattered background seismicity occurred during 1981 to 1991 (Fig. 10). This seismicity is distributed throughout the region, extending from the San Andreas fault in the south to the Lenwood fault in the north. The $M_{W} 6.2 \mathrm{Big}$ Bear earthquake and its aftershocks also occurred in this region, mostly along a northeast trend (Hauksson et al., 1993).

The focal mechanisms from the 1981 to 1991 and the 28 June to 31 December 1992 seismicity yield similar deviatoric stress tensors. These stress tensors have $S_{1}$ trending $\mathrm{N} 3^{\circ} \pm 5^{\circ} \mathrm{W}$ for both data sets, and the style of faulting is pure strike slip on northeast or northwest striking planes with $\phi=0.44 \pm 0.16$. To search for spatial variations, the 28 June to 31 December 1992 data 
set was divided into a north and south group, but no obvious variations were found. The absence of a stress change following the June $28 M_{W} 6.2$ earthquake can be explained in two different ways. First, the stress release caused by the $M_{W} 6.2 \mathrm{Big}$ Bear earthquake was small compared to the existing horizontal stresses. Second, the $M_{W} 7.3$ Landers mainshock loaded the region with additional stress that was mostly released by the Big Bear earthquake. The first explanation is more likely, because the stress change from the Landers earthquake was calculated to be only about 3 bars (Stein et al., 1992), whereas the stress drop in the Big Bear earthquake was about 100 bars (Kanamori et al., 1992).

\section{Discussion}

\section{Stress Release and Transfer}

The Landers rupture zone showed large variations in slip along strike and, in general, the surficial displacements were higher along the northern part of the rupture zone than along the southern part (Sieh et al., 1993).
Also, the slip derived from strong-motion records and Global Positioning System (GPS) showed significant spatial variability (e.g., Wald and Heaton, 1994; Hudnut et al., 1994). The stress state determined in this study showed similar changes along strike as the variations in slip, with $S_{1}$ becoming progressively more fault normal from south to north, suggesting that these changes were caused by the Landers mainshock (Fig. 8). The slip of $2 \mathrm{~m}$ or less to the south was insufficient to release the shear stress completely, while the slip of 4 to $6 \mathrm{~m}$ to the north appears to release most of the stored shear stress on these faults (Fig. 11). Because numerous small aftershocks occurred along the northern part of the rupture, some shear stress must still exist. Thus, on small spatial scales, the state of stress was heterogeneous and caused small aftershocks with very diverse focal mechanisms.

In the case of the 1989 Loma Prieta earthquake, Beroza and Zoback (1993) argued that uniaxial fault-normal compression implied that all the shear stress was released. In comparison, along the Emerson-Camp Rock faults, the residual stress has no uniform shear-stress component at all, and on the average, the two horizontal

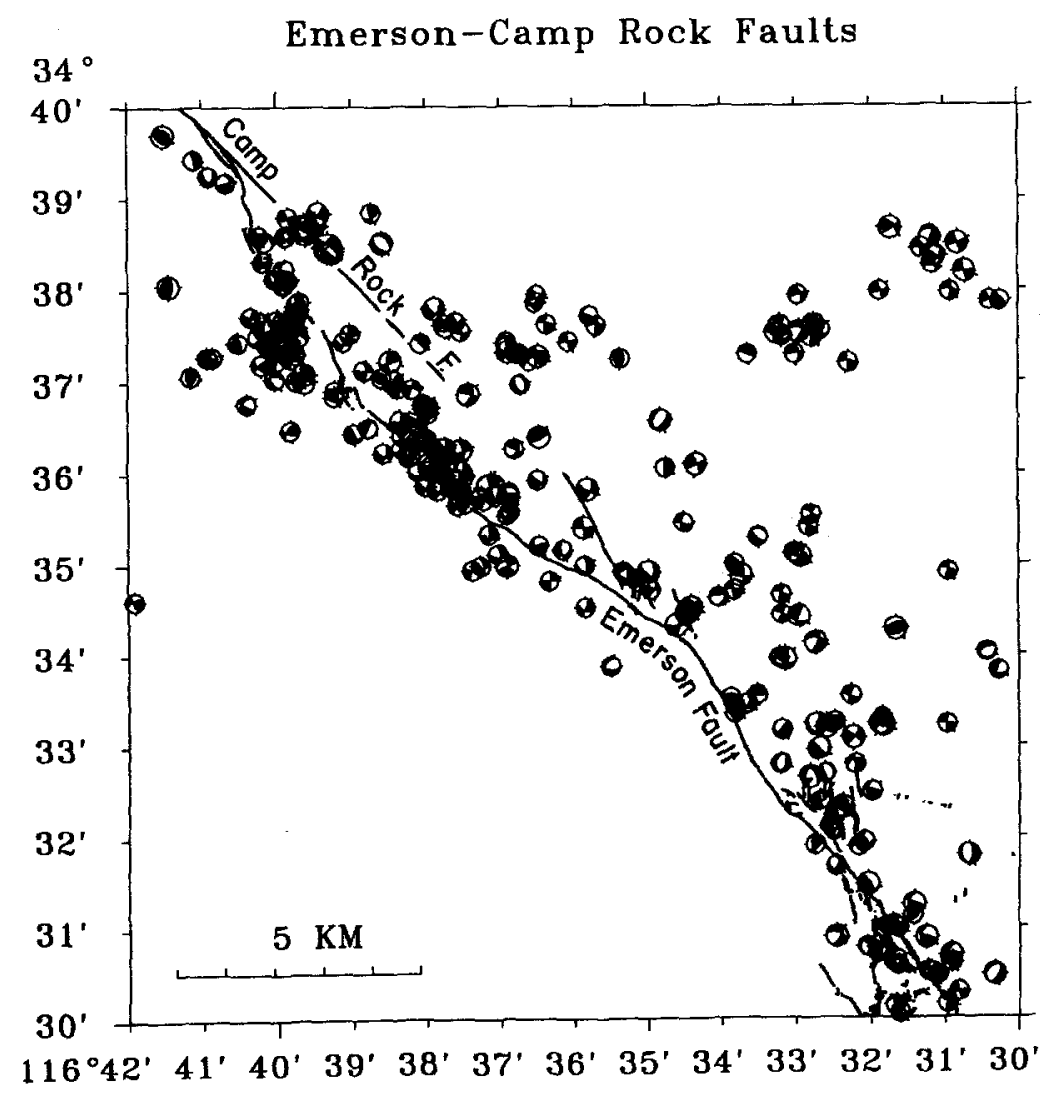

(a)

Figure 7. (a) Single-event lower-hemisphere focal mechanisms and (b) $P$ and $T$ axes of Landers aftershocks (June to December 1992) from the Emerson-Camp Rock fault area. 


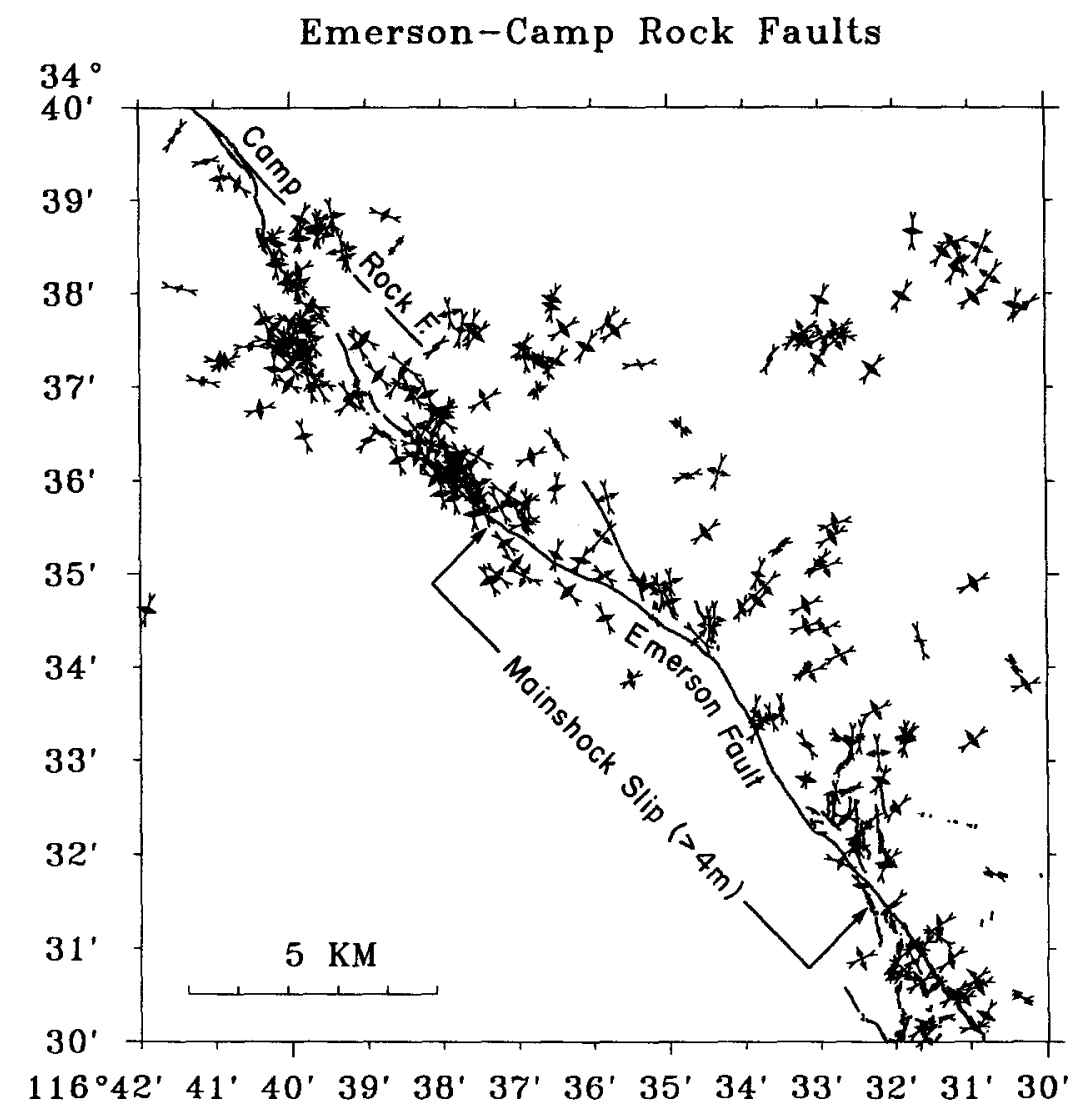

(b)

Figure 7-Continued

stresses may be of similar magnitude. The similar magnitudes of the horizontal stresses reflects a more complete stress release than was observed in the Loma Prieta earthquake. Alternatively, the different residual stress states may result from different initial stress conditions or residual stresses produced by the rupture along a nonplanar fault (e.g., Saucier et al., 1992).

In addition to regular aftershock activity near the mainshock rupture, the Landers earthquake was followed by significant off-fault aftershock activity such as the Barstow and Big Bear clusters. The results of this study show that the stress states before and after the Barstow cluster are similar. This suggests that this cluster did not release significant stress and that the Landers mainshock triggered this activity. Similarly, the deviatoric stress did not change near the Big Bear earthquake and its aftershocks, which may have released a small part of the existing stress field. The stress magnitudes in the San Bernardino Mountains may be larger than in the Mojave Desert, including Barstow, because of the bend in the San Andreas fault. If different initial stress conditions are allowed, both of these off-fault clusters of aftershocks, one with an $M_{W} 6.2$ main event, are consistent with models of the temporal stress transfer and triggering caused by the Landers mainshock (Harris and Simpson, 1992; Jaume and Sykes, 1992; Stein et al., 1992).

\section{Stress Recharge}

The temporal changes in the state of stress observed in the LSBM are unusual. These changes can be explained in terms of co-seismic stress release at the time of the 23 April $1992 M_{W} 6.1$ Joshua Tree earthquake and partial co-seismic stress recharge at the time of the 28 June $M_{W} 7.3$ Landers earthquake. Because the stress inversion provides only the deviatoric part of the stress tensor, it is not possible to tell if the absolute stress magnitudes have changed significantly. The 23 April stress release caused $S_{1}$ to trend more easterly by $9^{\circ}$ to $19^{\circ}$. At the time of the Landers mainshock of 28 June, the $S_{1}$ trend was reversed back to the trend prior to 23 April, although no slip occurred south of the Eureka Peak fault in the Landers mainshock. This is the first time that such a rapid partial stress recharge of a seismogenic zone has been documented.

The recharge can possibly be explained as an end effect from the mainshock and immediate aftershock ruptures that may have extended into the LSBM along 

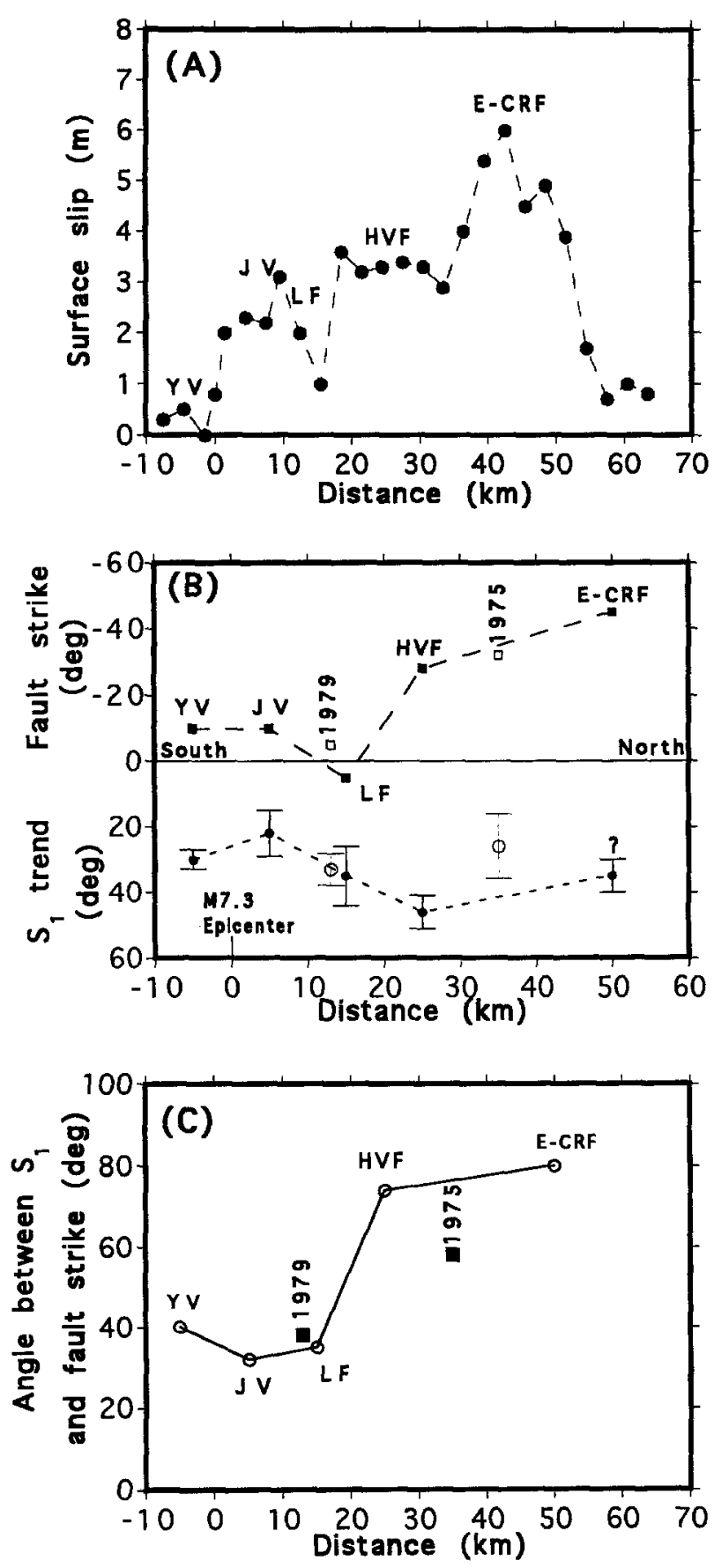

Figure 8. (a) Slip distribution along the surface rupture of the $1992 M_{W} 7.3$ Landers earthquake (Sieh et al., 1993). YV, Yucca Valley; JV, Johnson Valley; LF, Landers fault; HVF, Homestead Valley fault; and E-CRF, Emerson-Camp Rock fault. (b) Trend of $S_{1}$ and strike of fault segments versus distance along the Landers rupture zone. Open circles indicate the $S_{1}$ trend from the 1975 and 1979 data. Open squares indicate nodal planes of the 1975 and 1979 mainshocks, which align with the aftershock distribution. Solid squares indicate the strike of fault segments that ruptured in 1992. Solid circles indicate the $S_{1}$ trends from the 1992 aftershocks (see also Table 1). (c) The angle between the $S_{1}$ trend and the strike of each fault segment after the 1992 Landers earthquake.

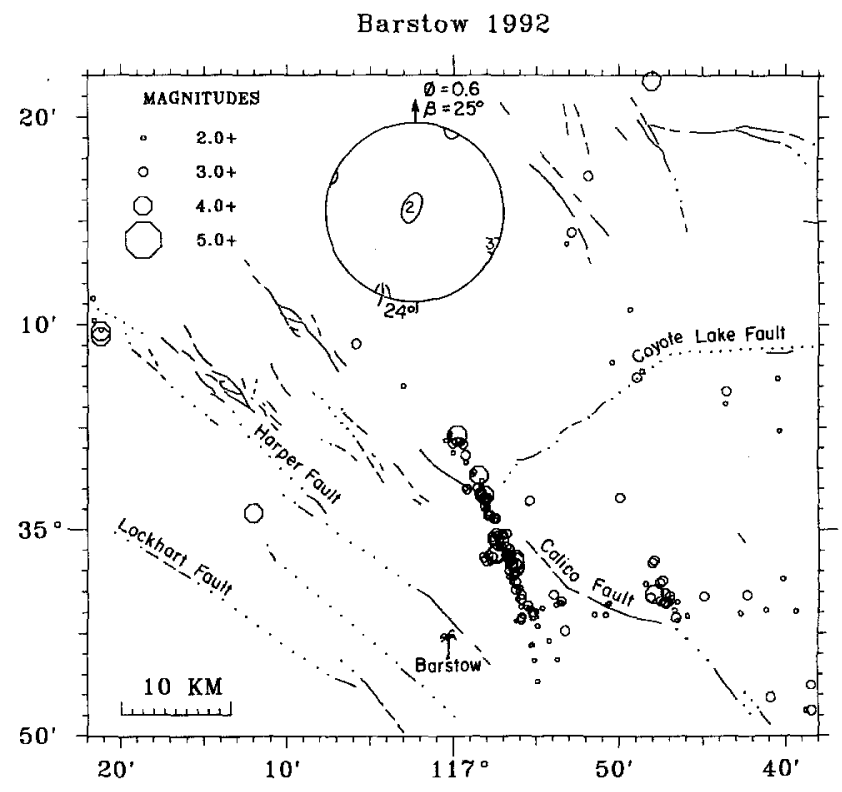

Figure 9. Results from the stress inversion of focal mechanisms from the Barstow region (see also Fig. 2 for labeling of stresses).

the Eureka Peak fault. It was followed by renewed aftershock activity (Hauksson et al., 1993). These aftershocks did not coincide in detail with the previous activity, but were located near its the western edge (Fig. 2).

It is unlikely that these temporal changes in the stress state are caused by a spatially heterogeneous stress field. In particular, the LSBM is a relatively small area, and such large spatial variations are rarely observed (e.g., Mount and Suppe, 1992). Furthermore, all three data sets spatially overlap, further reducing the likelihood of this explanation.

The $M_{W} 6.1$ Joshua Tree earthquake caused a significant stress rotation, while the $M_{W} 6.2$ Big Bear earthquake did not change the horizontal stress directions. This implies that the state of stress is somehow different in the two regions. One possible explanation is that in the San Bernardino Mountains, a region of high topography, the horizontal stresses are much larger than in the Joshua Tree region. The bend in the San Andreas fault, or possibly the negative buoyancy density anomaly beneath the Ranges (Sonder, 1990), may increase the horizontal stresses in this region.

\section{Style of Faulting}

The dominance of strike-slip faulting on north to northwest striking planes is characteristic of the ECSZ (Dokka, 1983; Dokka and Travis, 1990), where the 1992 Joshua Tree and Landers earthquakes occurred. In some places, $S_{1}$ trends north-northeast and the $S_{1}$ and $S_{2}$ are of similar size, causing the style of faulting on north to northwest striking planes to be transtensional. This is 

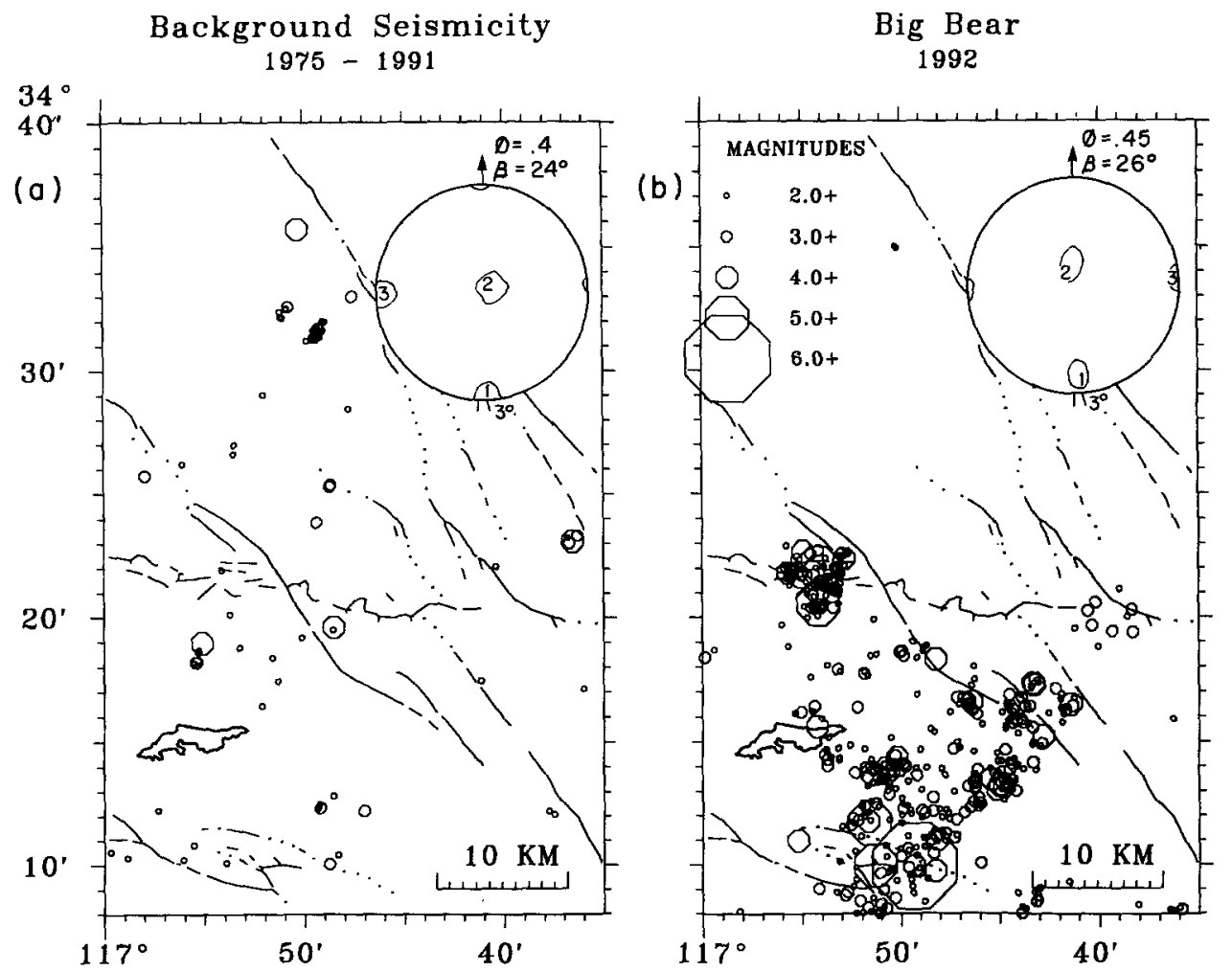

Figure 10. Results from the stress inversion of focal mechanisms from the San Bernardino Mountains. (a) The background seismicity from 1981 to 1991; (b) the post 28 June 1992 aftershocks (see also Fig. 2).

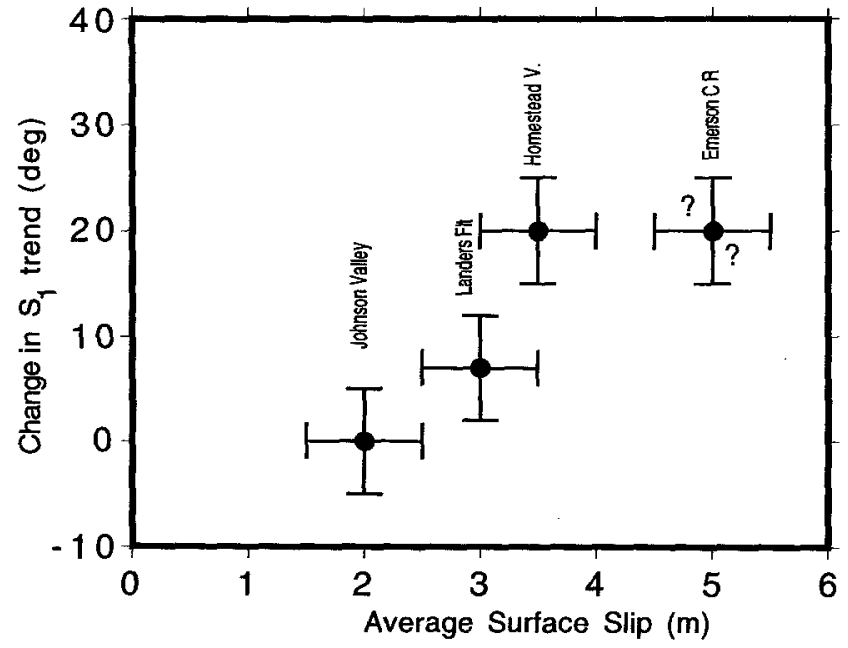

Figure 11. Changes in $S_{1}$ trend from before and after the $M_{W} 7.3$ Landers earthquake. The Emerson-Camp Rock data point is marked with question marks to indicate uncertainty in the $S_{1}$ trend determination. consistent with most geological observations of faulting within the Mojave Desert (e.g., Dibblee, 1967; Dokka and Travis, 1990).

In contrast, Bartley et al. (1990) suggested that the Mojave Desert was being deformed via north-south contraction. In particular, the Barstow region, where the Barstow aftershock cluster occurred, is a site of numerous anticlines and synclines that are younger than 13million yr old, suggesting north-south contraction of the Mojave Desert (Bartley et al., 1990). An alternative way of explaining the folds is via dextral faulting that causes some rotation of rigid crustal blocks or localized compression near fault steps. The Landers sequence and the stress inversion results from this study show that the strike-slip faulting presently is the predominant mode of deformation in the Mojave Desert.

In the San Bernardino Mountains, the majority of the earthquakes have strike-slip focal mechanisms with northwest and northeast nodal planes, and the state of stress is dominantly strike slip. The thrust faults that bound 


\section{Eastern California Shear Zone Stress State}

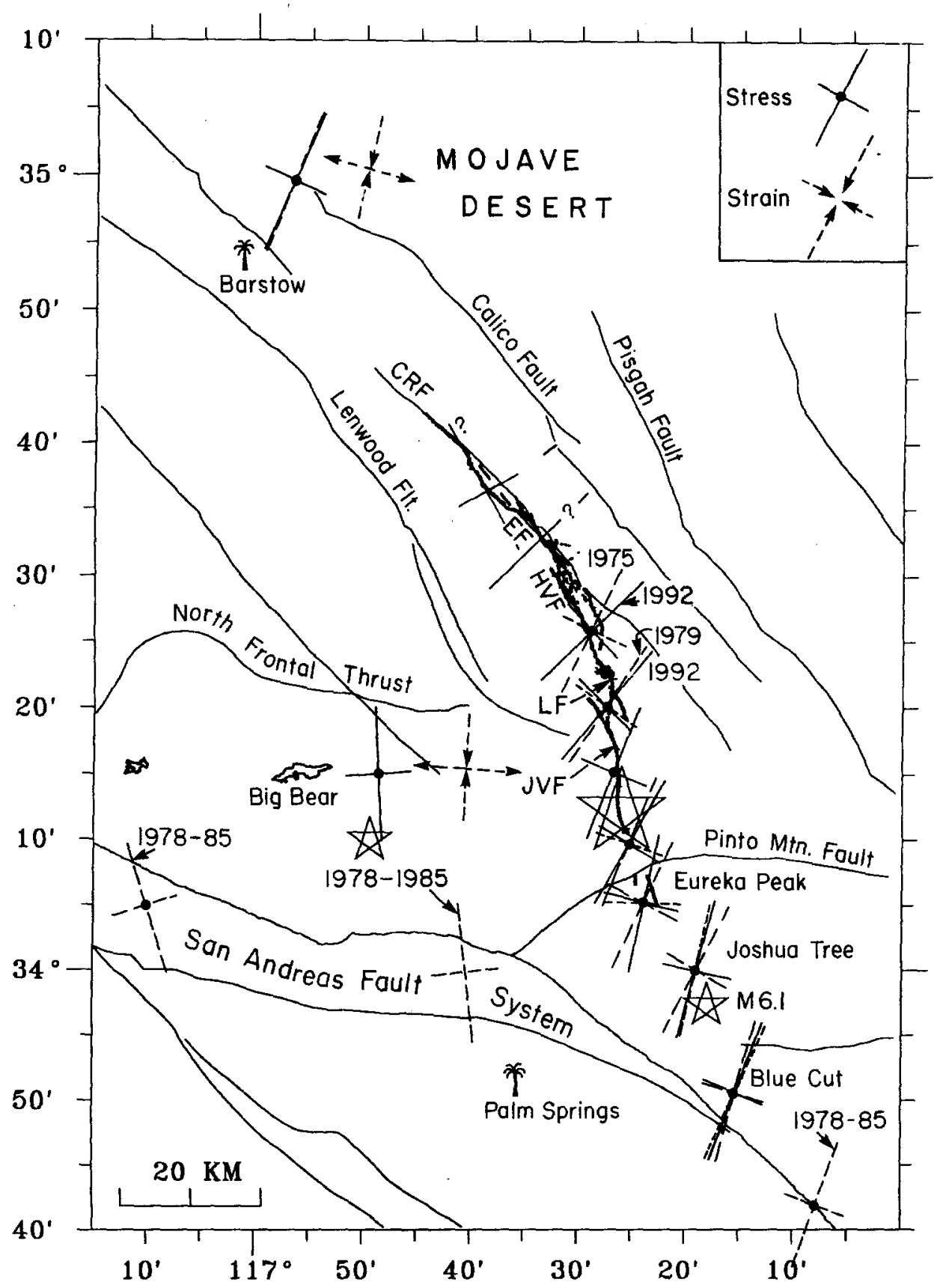

Figure 12. Summary of the $S_{1}$ trends in the eastern California shear zone and along the San Andreas fault zone. The $S_{1}$ trends labeled 1978 to 1985 are from Jones (1988). The stars indicate the epicenters of the $M_{W} 6.1$ Joshua Tree, $M_{W}$ 7.3 Landers, and $M_{W} 6.2$ Big Bear earthquakes. The geodetic strain data are from Savage et al. (1990). CRF: Camp Rock fault. The different $S_{1}$ trends are labeled with the respective year (see also Table 1). The question marks near the $S_{1}$ trends near the Emerson and Camp Rock faults indicates that the results of the stress inversion are questionable because of the large misfit. In the Joshua Tree area, each set of three $S_{1}$ trends are shown as 1981 to 1991 data (short dashes), 23 April to 27 June 1992 (long dashes), and 28 June to 31 December 1992 (solid lines). 
the mountains, such as the North Frontal Thrust fault, do not seem to be active at the present time (Hauksson et al., 1993). Thus, crustal blocks are being transferred laterally to accommodate motion around the San Andreas fault, without crustal thickening (Weldon and Humphreys, 1986).

\section{Regional Stress Refractors}

The $S_{1}$ trends determined in this study and the $S_{1}$ trends from Jones (1988) near the southern San Andreas fault (SAF) are shown in Figure 12. Near the SAF, the $S_{1}$ trend rotates with the strike of the SAF and forms a high angle $\left(43^{\circ}\right.$ to $\left.68^{\circ}\right)$ with the fault strike. In the adjacent San Bernardino Mountains, the $S_{1}$ trend is $\mathrm{N} 3^{\circ} \pm$ $5^{\circ} \mathrm{W}$, which may be influenced by the bend in the San Andreas fault (Jones, 1988) or the density anomaly beneath the San Bernardino Mountains (Sonder, 1990). To the east and northeast in the ECSZ, the $S_{1}$ trend ranges from $\mathrm{N} 20^{\circ} \mathrm{E}$ to $\mathrm{N} 44^{\circ} \mathrm{E}$. Some of the rotation of $S_{1}$ to the east is a temporal anomaly that was caused by the 1992 $M_{W} 7.3$ Landers mainshock. The remaining part of the $S_{1}$ rotation to the east is a permanent feature of the stress field. One possible explanation for such a permanent rotation is that the ECSZ is a weak zone that refracts the local stress field.

To explain the state of stress in southern California, the SAF has been proposed as a stress refractor, controlling the state of stress out to distances of $100 \mathrm{~km}$ (Zoback et al., 1987). The results of this study suggest that the ECSZ is also a significant stress refractor, although it has a less pronounced effect on the stress field than the SAF. The ECSZ rotates the trend of $S_{1}$ about $10^{\circ}$ to $30^{\circ}$ to the east of north, more than would be expected from the effect of the SAF (Fig. 12).

Geodetic and geological evidence also suggest that the ECSZ is a stress refractor. The ECSZ concentrates shear strains to the east of the SAF and is sheared in a right-lateral sense at a rate of about $8 \mathrm{~mm} / \mathrm{yr}$ (Sauber $e t$ al., 1986; Savage et al., 1990). This deformation rate is about 20 to $30 \%$ of the rate of deformation along the San Andreas fault itself. Furthermore, the cumulative offsets on the faults within the ECSZ are consistent with the ECSZ having been sheared for several million years (Dokka and Travis, 1990).

The presence of more than one stress refractor in southern California explains the state of stress better than the presence of only one refractor, the SAF. While the ECSZ forms a stress refractor to the east of the SAF and the San Jacinto, Elsinore-Whittier and faults in the Los Angeles basin form stress refractors to the west. In particular, Hauksson (1990) showed that significant rotations of $S_{1}$ occur in the Los Angeles basin, suggesting the presence of a localized stress refractor. In addition to stress refractors, possible density anomalies beneath the Transverse Ranges (Sonder, 1990) may also affect the stress field.

\section{Conclusions}

The ECSZ is a weak zone that refracts the local stress field in a manner similar to the San Andreas fault in southern California. The ECSZ rotates the $S_{1}$ trend about $10^{\circ}$ to $30^{\circ}$ clockwise. The change in $S_{1}$ trend to a progressively more fault-normal azimuth toward the north is consistent with a hypothesis that the higher mainshock slip along the northern part ( 4 to $6 \mathrm{~m}$ ) of the rupture compared with the southern part ( 1 to $3 \mathrm{~m}$ ) represents a greater release of stress in the north and only partial release to the south. The predominantly fault-normal $S_{1}$ trend suggests that the mainshock released nearly all of the applied shear stress along the northern half of the fault rupture. The complex residual state of stress that has both horizontal stresses of similar average magnitude caused a diversity of focal mechanisms along the Emerson-Camp Rock faults. The distant aftershock cluster near Barstow may have been triggered by the Landers mainshock. The Big Bear earthquake may have released some of the existing large-magnitude stress field. The 23 April $M_{W} 6.1$ Joshua Tree earthquake rotated the $S_{1}$ trend to the east by $9^{\circ}$ to $19^{\circ}$. The 28 June $M_{W} 7.3$ Landers mainshock rotated the $S_{1}$ trend to the trend prior to 23 April, providing a rapid partial recharge of a seismogenic fault zone. The style of faulting in the ECSZ is strike slip on north to north-northwest striking planes, and in some cases, strike slip with some normal component or transtensional.

\section{Acknowledgments}

D. Wald, J. Stock, H. Kanamori, L. Jones, and two BSSA reviewers R. Weldon and R. Dokka provided helpful critical comments and reviews. I thank Kerry Sieh for stimulating discussions about the tectonics of the Landers earthquake and for providing a map of the surface rupture. I am grateful to the seismic analysts of Caltech and the USGS for quick and competent processing of the earthquake data. This research was partially supported by USGS Grant No. 14-08-0001-G1761 and USGS cooperative agreement 1434-92-A-0960 to Caltech and the Southern California Earthquake Center (SCEC) under NSF cooperative agreement No. EAR-8920136 and USGS cooperative agreement No. 14-08-0001-A0899. SCEC publication No. 74. Contribution No. 5318, Division of Geological and Planetary Sciences, California Institute of Technology, Pasadena, California 91125.

\section{References}

Bartley, J. M., A. F. Glazner, and E. R. Schermer (1990). Northsouth contraction of the Mojave Block and strike-slip tectonics in southern California, Science 248, 1398-1401.

Beroza, G. C. and M. D. Zoback (1993). Mechanism diversity of the Loma Prieta aftershocks and the mechanics of mainshock-aftershock interaction, Science 259, 210-213.

Dibblee, T. W., Jr. (1967). Areal geology of the western Mojave Desert, California, U.S. Geol. Surv. Profess. Pap. 522, 1-153.

Dokka, R. K. (1983). Displacements on late Cenozoic strike-slip faults of the central Mojave Desert, California, Geology 11, 305-308.

Dokka, R. K. and C. J. Travis (1990). Late Cenozoic strike-slip faulting in the Mojave Desert, California, Tectonics 9, 311-340. 
Harris, R. A. and R. W. Simpson (1992). Changes in static stress on southern California faults after the 1992 Landers earthquake, $\mathrm{Na}$ ture 360, 251-254.

Hartse, H., R. Aster, M. Fehler, J. Scott, and F. Vernon (1994). Evidence for small-scale stress heterogeneity in the Anza Seismic Gap, Southern California, J. Geophys. Res. 99, 6801-6818.

Hauksson, E. (1990). Earthquakes, faulting and stress in the Los Angeles Basin, J. Geophys. Res. 95, 15365-15394.

Hauksson, E., L. M. Jones, K. Hutton, and D. Eberhart-Phillips (1993). The 1992 Landers earthquake sequence: seismological observations, J. Geophys. Res. 98, 19835-19858.

Hudnut, K. W., Y. Bock, M. Cline, P. Fang, Y. Feng, J. Freymueller, X. Ge et al. (1994). Coseismic displacements of the 1992 Landers earthquake sequence, Bull. Seism. Soc. Am. 84, no. 3, 625-645.

Jaume, S. C. and L. R. Sykes (1992). Changes in state of stress on the southern San Andreas Fault resulting from the California earthquake sequences of April to June 1992, Science 258, 13251328

Jennings, C. W. (1975). Fault map of California with volcanoes, thermal springs and thermal wells, 1:750,000 scale, geol. data map 1, Calif. Div. Mines Geol., Sacramento.

Jones, L. M. (1988). Focal mechanisms and the state of stress on the San Andreas fault in southern California, J. Geophys. Res. 93, $8869-8891$.

Kanamori, H., H.-K. Thio, D. Dreger, E. Hauksson, and T. Heaton (1992). Initial investigation of the Landers, California, earthquake of 28 June 1992 using TERRAscope, Geophys. Res. Lett. 19 , 2267-2270.

Michael, A. J. (1984). Determination of stress from slip data: faults and folds, J. Geophys. Res. 89, 11517-11526.

Michael, A. J. (1987a). The use of focal mechanisms to determine stress: a control study, J. Geophys. Res. 92, 357-368.

Michael, A. J. (1987b). Stress rotation during the Coalinga aftershock sequence, J. Geophys. Res. 92, 7963-7979.

Michael, A. J. (1991). Spatial variations in stress within the 1987 Whittier Narrows, California, aftershock sequence: new techniques and results, J. Geophys. Res. 96, 6303-6319.

Michael, A. J., W. L. Ellsworth, and D. Oppenheimer (1990). Coseismic stress changes induced by the 1989 Loma Prieta, California earthquake, Geophys. Res. Lett. 17, 1441-1444.

Mount, V. S. and J. Suppe (1987). State of stress near the San Andreas fault: implications for wrench tectonics, Geology 15, $1143-$ 1146.

Mount, V. S. and J. Suppe (1992). Present-day stress orientations adjacent to active strike-slip faults: California and Sumatra, $J$. Geophys. Res. 97, 11995-12013.

Reasenberg, P. and D. Oppenheimer (1985). FPFIT, FPPLOT and FPPAGE: Fortran computer programs for calculating and dis- playing earthquake fault-plane solutions, U.S. Geol. Surv. OpenFile Rept. 85-739, 109 pp.

Reasenberg, P. A. and R. W. Simpson (1992). Response of regional seismicity to the static stress change produced by the Loma Prieta earthquake, Science 255, 1687-1690.

Rymer, M. J. (1992). The 1992 Joshua Tree, California, earthquake: tectonic setting and triggered slip (abstracts), EOS 73, 363.

Saucier, F., E. Humphreys, and R. Weldon (1992). Stress near geometrically complex strike-slip faults: application to the San Andreas Fault at Cajon Pass, southern California, J. Geophys Res. 97, 5081-5094.

Sauber, J., W. Thatcher, and S. C. Solomon (1986). Geodetic measurements of deformation in the central Mojave Desert, California, J. Geophys. Res. 91, 12683-12693.

Savage, J. C., M. Lisowski, and W. H. Prescott (1990). An apparent shear zone trending north-northwest across the Mojave Desert into Owens Valley, eastern California, Geophys. Res. Lett. 17, 2113-2116.

Sieh, K., L. Jones, E. Hauksson, K. Hudnut et al. (1993). Near-field investigations of the Landers Earthquake Sequence, April to July 1992, Science 260, 171-176.

Sonder, L. (1990). Effects of density contrasts on the orientation of stresses in the lithosphere: relation to principal stress directions in the Transverse Ranges, California, Tectonics 9, 761-771.

Stein, R. S., G. C. P. King, and J. Lin (1992). Change in failure stress on the San Andreas and surrounding faults caused by the $1992 \mathrm{M}=7.4$ Landers earthquake, Science 258, 1328-1332.

Wald, D. J. and T. H. Heaton (1994). Spatial and temporal distribution of slip for the 1992 Landers, California earthquake, Bull. Seism. Soc. Am. 84, no. 3, 668-691.

Weldon, R. J. and E. Humphreys (1986). A kinematic model of southern California, Tectonics 5, 33-48.

Williams, P. L., L. R. Sykes, C. Nicholson, and L. Seeber (1990). Seismotectonics of the easternmost Transverse Ranges, California: relevance for seismic potential of the southern San Andreas Fault, Tectonics 9, 185-204.

Zoback, M. D. and G. C. Beroza (1993). Evidence for near-frictionless faulting in the 1989 (M 6.9) Loma Prieta, California, earthquake and its aftershocks, Geology 21, 181-185.

Zoback, M. D., M. L. Zoback, V. S. Mount, J. Suppe, J. P. Eaton, J. H. Healy, D. Oppenheimer, P. Reasenberg, L. Jones, C. B. Raleigh, I. G. Wong, O. Scotti, and C. Wentworth (1987). New evidence on the state of stress of the San Andreas Fault system, Science 238, 1105-1111.

Seismological Laboratory

California Institute of Technology

Pasadena, California 91125

Manuscript received 18 August 1993. 